\title{
River water quality assessment based on a multi-descriptor approach including chemistry, diatom assemblage structure, and non-taxonomical diatom metrics
}

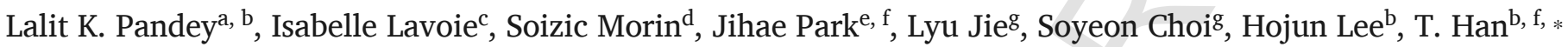 \\ a Institute of Green Environmental Research Center, 169, Gaetbeol-ro, Yeonsu-gu, Incheon 21999, Republic of Korea \\ ${ }^{\mathrm{b}}$ Department of Marine Sciences, Incheon National University, 119, Academy-ro, Yeonsu-gu, Incheon 22012, Republic of Korea \\ ${ }^{\mathrm{c}}$ Institut National de la Recherche Scientifique, Centre Eau Terre Environnement, 490 rue de la Couronne, Québec City, Québec G1 K 9A9, Canada \\ ${ }^{\mathrm{d}}$ Irstea, UR EABX,50 Avenue de Verdun 33612 Cestas Cedex, France \\ e Department of Plant Biotechnology and Bioinformatics, Ghent University Global Campus, 119, Songdomunwha-ro, Yeonsu-gu, Incheon 21985, Republic of Korea \\ ${ }^{\mathrm{f}}$ Ghent University Global Campus, 119, Songdomunwha-ro, Yeonsu-gu, Incheon 21985, Republic of Korea \\ ${ }^{g}$ Department of Life Sciences, Incheon National University, 119, Academy-ro, Yeonsu-gu, Incheon 22012, Republic of Korea
}

\section{A R T I C L E IN F O}

\section{Keywords:}

Biomonitoring

Diatoms

Lipid bodies

Deformities

Diatom assemblages

Diversity

Cell size

\begin{abstract}
A B S T R A C T
In the present study, the ecological status of four major South Korean rivers flowing near industrial complexes is assessed using physico-chemical analyses and various descriptors based on periphytic diatom assemblages. Principal component analysis conducted with physical and chemical variables singled-out four sites as more severely impacted (higher concentration of metals and total nitrogen, higher conductivity and biological oxygen demand), while the remaining 12 sites indicated less impacted conditions, although showing nutrient enrichment. Less-contaminated sites based on physico-chemical properties showed higher cell densities, higher richness and diversity, a larger proportion of live and healthy-looking diatoms, lower production of lipid bodies (in terms of number and size) and fewer teratologies than more-contaminated sites. Non-taxonomical metrics (cell heath status, cell size, lipid bodies and valve deformities) were in good agreement with traditional taxonomical metrics (assemblage structure, richness, diversity). Overall, water quality assessment based on diatom assemblages and diatom-based metrics had a good fit with the available physico-chemical data and agreed on the most impacted sites. However, additional sites showed signs of degradation based on the diatom metrics used. This suggests that the use of biotic indicators provides useful complementary information on the health status at the selected sites.
\end{abstract}

\section{Introduction}

Industrialization and urbanization contribute to freshwater ecosystem degradation worldwide. Alteration and channelization of watercourses in urban areas result in progressive hydrological and hydrobiological degradation that may have serious impacts on the biotic and abiotic components of these systems. For example, urban watercourses may suffer from elevated and fluctuating concentrations of nutrients and contaminants (e.g., metals, pesticides, aromatic polycyclic hydrocarbons), causing changes in species assemblage composition, with increases in the number and abundance of pollution-tolerant species (Morin et al., 2012).

Water quality programs targeting chemical criteria alone have been criticized, as they do not provide information on the impacts of envi- ronmental stresses on organisms (Lavoie et al., 2008a,b; Wolska et al., 2007). The aquatic biota, however, responds in a complex and dynamic manner to cumulative effects of various anthropogenic disturbances, and thus provides an integrated picture of the biological health of an ecosystem. Bioindicators therefore represent a crucial component for assessing overall ecological health (Ricciardi et al., 2009), and are a valuable complement to traditional physico-chemical measurements.

There is growing interest in studying the response of aquatic biota to various environmental stresses, its resilience, and its recovery trajectories. Due to its key ecological role at the base of the food web, sessile mode of life, cosmopolitan nature, and short life cycle, the algal component of biofilms is often selected for its sensitive and rapid response to environmental fluctuations as compared with higher-level organisms. In particular, diatoms (Bacillariophyta) have been extensively included in water quality assessment for monitoring the biological in-

\footnotetext{
* Corresponding author at: Department of Marine Science, Incheon National University, 119, Academy-ro, Yeonsu-gu, Incheon 22012, Republic of Korea.

Email address: hanalgae@hanmail.net (T. Han)
} 
tegrity of lotic ecosystems under various stresses such as eutrophication, salinization, as well as metal and organic contamination (Gold et al., 2002; Debenest et al., 2008; Lavoie et al., 2014). Diatoms are a group of algae exhibiting a large diversity in terms of taxonomy, morphology and ecology, and are present in most aquatic and humid environments (Round et al., 1990). Diatoms have specific degrees of tolerance to environmental variables and have a rapid reproduction rate, which are among the characteristics making them excellent indicators of aquatic biological integrity (Kelly et al., 2008; Stevenson et al., 2008, 2010). Subtle changes in environmental conditions may cause a shift in assemblage structure; sensitive diatoms decrease in abundance, while tolerant species increase (Van Dam et al., 1994; Harding et al., 2005). The analysis of the diatom assemblage structure and species' autecology allows for the characterization of past and present environmental conditions and health status in a system (Kelly et al., 2008; Leira et al., 2015; Schallenber and Saulnier-Tablbot, 2015). Diatom-based monitoring is also gaining in popularity for the assessment of ecosystem rehabilitation to evaluate recovery success (e.g., Coe et al., 2009; Feld et al., 2011; Arini et al., 2012; Hamilton et al., 2015; Żelazna-Wieczorek and Nowicka-Krawczyk, 2015).

To adequately estimate the biological status of a system before and after alteration or rehabilitation, it is fundamental to develop appropriate biological metrics. An approach based on multiple descriptors may provide a more complete and integrated picture of the environmental conditions experienced by the diatoms, as compared with the more traditional taxonomic approach (assemblage structure) generally used in the development of diatom-based indices (Kelly and Whitton, 1995; Ponader et al., 2007; Coste et al., 2009; Lavoie et al., 2006, 2014). Multi-metric diatom indices have already been developed (Zalack et al., 2010), but generally include taxonomy-derived metrics such as\% tolerant species, richness and chlorophyll $a$ (Fore and Grafe, 2002). Various non-taxonomic diatom descriptors such as cell health status, motility, lipid bodies, cell density and teratologies (abnormal valves) are well documented as biomonitoring tools. For example, Morin et al. (2012) reviewed the response of diatoms to metal contamination from the individual level (e.g., size, growth form, and morphological abnormalities) to the assemblage structure level (turnover from sensitive to tolerant species). Similarly, Pandey and Bergey (2016) used various metrics to monitor the effect of chronic metal exposure ( $\mathrm{Cu}$ and $\mathrm{Zn}$ ) on benthic diatoms, and reported a reduction in diatom motility and cell size, as well as an increase in lipid body content and in teratology frequency.

In this study, benthic diatom assemblages from 16 sites selected along four major South Korean rivers flowing in close proximity to industrial complexes and municipal effluents were examined to evaluate their ecological status. For this purpose, multiple biological descriptors were used. First, more traditional metrics based on diatom assemblage composition, richness, diversity and cell density were examined. Additional biological metrics were also investigated: cell size distribution, diatom health status (live, unhealthy or dead), and the presence of lipid bodies and teratologies. Finally, we compared the information provided by the various diatom-based metrics examined with the estimation of the water quality status of each site based on a suite of physico-chemical characteristics.

\section{Materials and methods}

\subsection{Study area and site selection}

The Korean Ministry of the Environment (MOE) performs regular water quality assessment of streams and rivers, including numerous variables such as metals, total phosphorus (TP) and total nitrogen (TN), biological oxygen demand $\left(\mathrm{BOD}_{5}\right)$, total dissolved solids (TDS), $\mathrm{pH}$, conductivity and total coliforms. The South Korean government also re- cently conducted an extensive study on micro-pollutants (measured at 159 sites impacted by effluents from 34 industrial complexes) in four major watersheds, and results from this project are summarized in Cho et al. (2014). Based on the available information (eight years of regular monitoring performed by the South Korean government; 2008-2015), 16 sites were selected on the basis of potential chronic contamination from industrial effluents (Fig. 1). Sites were chosen in such a manner as to cover various sub-watersheds across South Korea. Additional information on the sampling sites and on the four watersheds is provided as supplementary material (S1 and S2).

\subsection{Surface water sampling and analyses}

On-site water quality measurements and surface water collection were performed in September 2015 at the 16 selected sites following the guidelines of the National surveys for stream ecosystem health (MOE, Korea). Temperature, $\mathrm{pH}$, and dissolved oxygen were measured directly in the field with a multi-parameter display system (YSI 650, USA). Conductivity was measured in the field with a portable meter (Milwaukee, USA). Total dissolved solid measurements were performed in the field with an amperometric graphite electrode (HI98301 DiST ${ }^{\circledR} 1$ ). Biochemical oxygen demand was measured by dark and light bottle incubation for $24 \mathrm{~h}$ at $20{ }^{\circ} \mathrm{C}$ in controlled light conditions. EPA-approved Colilert-18 test by IDEXX was carried out to estimate total coliforms. A water automatic analyzer (Skalar/Netherlands, SAN ++ ) was used to measure total nitrogen (TN) and total phosphorus (TP). Analyses of metals (As, Ag, Cd, Cr, Cu, Hg, Ni, Pb and $\mathrm{Zn}$ ) were conducted by inductively coupled plasma-optical emission spectrophotometer (ICP-OES; Varian Vista PRO, CA, USA) using $15 \mathrm{ml}$ water samples. Standard solutions were prepared fresh and calibration curves $\left(r^{2}>0.995\right)$ were performed. To ensure the quality of the measurements, standard solutions were analyzed after every 10 samples to verify their concentrations. Measurement precision ranged from 94 to 107\%, and detection limits were calculated based on the standard deviations of blanks triplicates (range: $4-14 \mu \mathrm{g} \mathrm{L}^{-1}$ ). Organic compounds were analyzed by the South Korean Ministry of the Environment, following the methods presented in Cho et al. (2014). All samples collected for analyses of metals and organic compounds were previously filtered through $0.45 \mu \mathrm{m}$ filters.

\subsection{Periphytic diatom sampling and fresh material analyses}

Periphytic diatom assemblages were collected in September 2015 from hard surfaces (concrete walls, scrapped surface area $\sim 25 \mathrm{~cm}^{2}$ ) using a new toothbrush at each of the 16 selected sites. Six samples from each site were collected and pooled together to obtain a composite sample (Winter and Duthie, 2000; Lavoie et al., 2006). The collected material was placed in a plastic bottle with $5 \mathrm{ml}$ of river water, kept cold and transported to the laboratory, and analyzed within one week. Fresh samples were analyzed under a light microscope at 450x and 100x magnification (Zeiss, Axioskop 2, equipped with a Nikon camera) for live diatom observation. All diatom cells were counted to estimate densities with a Spencer's haemocytometer at 450× magnification using three aliquots of $1 \mathrm{ml}$ (pseudo-replicates, $\mathrm{n}=3$ ) of composite periphyton sample. Fresh diatom cells were examined to evaluate health status (live, unhealthy and dead cells), and for the presence of lipid bodies (LBs). Diatom cells were categorized as live or healthy (with intact chloroplasts), unhealthy (with distorted/degraded chloroplasts) and dead (empty frustules) (Gillet et al., 2009, 2011; Pandey et al., 2017). LBs were investigated in the living diatom cells following the protocol of Pandey et al. (2015). Briefly, a lipophilic fluorescent dye (4,4-difluoro-1,3,5,7-tetramethyl-4-bora-3a,4adiaza-s-indacene; BODIPY 505/ 515, Life technologies ${ }^{\circledR}$, USA) was used to stain the lipid bod- 


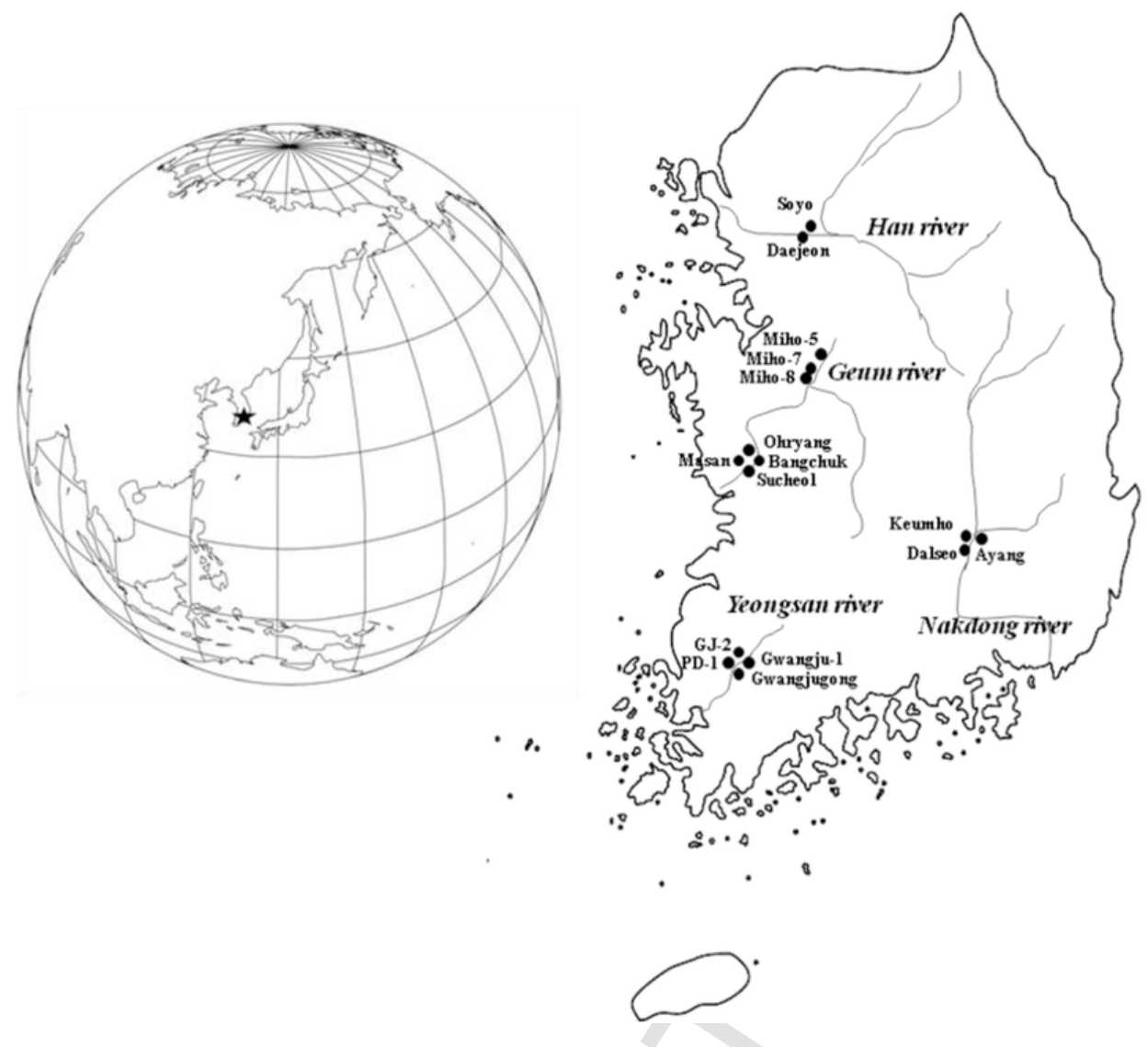

Fig. 1. Study area showing the 16 sites selected on four main Korean rivers.

ies inside the diatom cells, and the samples were examined using fluorescence microscopy (Carl Zeiss/LSM 700; USA, equipped with a WIG filter set for chlorophyll fluorescence). Excitation was at $450-490 \mathrm{~nm}$ and emission wavelengths were imaged through a $515 \mathrm{~nm}$-long pass filter. Stained lipid bodies (green) are easily distinguished from chloroplasts (red) in the diatom cells. LBs in each individual living diatom species were counted and measured at $400 \times$ and $1000 \times$ magnification. Biovolume of individual lipid droplets was calculated considering that LBs are more or less spherical, thus applying the formula $V=4 / 3 \pi r^{3}$, where $\mathrm{V}$ is the volume of the sphere and $\mathrm{r}$ is the radius of the lipid droplet. The total relative contribution of all LBs inside individual diatom cells was estimated by adding the biovolume of each lipid body divided by the biovolume of the frustules. A total of 100 live frustules were observed in each pseudo-replicate for each of the above-mentioned metrics (cells health status, lipid bodies, densities).

\subsection{Taxonomical analysis and assessment of teratologies}

Clean diatom frustules were also examined after digesting cell content to facilitate taxonomical identification and to assess the presence of abnormal valves. The fresh material collected was first treated with $90 \%$ acetone to remove cytoplasmic content. Subsequently, the samples were dried for $30 \mathrm{~min}$ at $25{ }^{\circ} \mathrm{C}$ and treated with concentrated $\mathrm{H}_{2} \mathrm{SO}_{4}$ (99.99\%, analytical grade, Sigma-Aldrich, St. Louis, MO63103, USA) followed by hydrogen peroxide (30\%) (w/w, analytical grade, Sigma-Aldrich, St. Louis, MO63103, USA). The cleaned samples were then washed 10 times with deionized water to remove the acid present inside the cells and in the liquid fraction. Diluted samples were spread onto cover slips for drying. Permanent slides were mounted in Pleurax mounting medium (refractive index $=1.73$ ) for microscopic examination. Diatoms were counted and identified using images from Algae- base (Academy of Natural Sciences of Philadelphia, http://diatom. acnatsci.org/AlgaeImage/) and the Algal image database of India (AIDI) (Pandey et al., 2016). Monographs on diatoms by Patrick and Reimer $(1966,1975)$ and a manual on stream periphyton by Biggs and Kilroy (2000) were also consulted. A total of 500 valves per sample were enumerated. Diatom assemblage composition was expressed as percent relative abundance. Qualitative and quantitative assessments of valve deformities were conducted using permanent diatom slides $(n=3)$. Deformities in diatom frustules were categorized into five types: (1) deformities in valve outline, (2) deformities in striations, (3) deformities in the sternum/raphe structure, (4) mixed deformities and (5) deformities in the costae (Falasco et al., 2009a; Pandey et al., 2014, 2015). Diatom cell biovolumes were classified in three categories based on Omnidia database (https://hydrobio-dce.irstea.fr/telecharger/diatomees-ibd/): small $\left(<400 \mu \mathrm{m}^{3}\right)$, intermediate $\left(400-4000 \mu \mathrm{m}^{3}\right)$, and large $\left(>4000 \mu \mathrm{m}^{3}\right)$.

\subsection{Statistical analyses}

Shannon's diversity index values were calculated using the freeware "PAST" (Hammer et al., 2001) for each pseudo-replicate $(n=3)$. A preliminary detrended correspondence analysis was conducted on species data and revealed a short gradient length (1.06) suggesting a linear response. Principal component analyses (PCAs; Euclidian distance) were thus conducted to explore site distribution based on (i) physico-chemical variables and (ii) diatom species assemblages. Environmental data were centered and standardized. Diatom relative species abundances were square root transformed. Only the species present at a relative abundance of $\geq 1 \%$ (in at least one sample) were included in the PCA. Ordinations were performed with the software CANOCO 5.0 (ter Braak and Šmilauer, 2012). 


\section{Results and discussion}

\subsection{Environmental characteristics of the study sites}

Values of the chemical and physical variables measured at the 16 sites are presented in Table 1 . Three metals detected in water samples were above quantification limits with elevated values: $\mathrm{Cu}$ $\left(\right.$ Keumho $\left.=0.048 \mathrm{mg} \mathrm{l}^{-1}\right), \quad \mathrm{Zn} \quad\left(\right.$ Daejeon $\left.=0.44 \mathrm{mg} \mathrm{l}^{-1}\right), \quad \mathrm{Ni}$ $\left(\right.$ Dalseo $\left.=0.068 \mathrm{mg} \mathrm{1}^{-1}\right)$. Certain sites showed elevated conductivity values (Soyo, Dalseo, Keumho, Daejeon $>2000 \mu \mathrm{S} \mathrm{cm}{ }^{-1}$ ) and coliforms

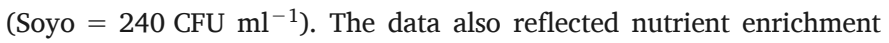
at most sites with mean TP reaching $0.141 \mathrm{mg} \mathrm{l}^{-1}\left(\right.$ range $=0.013-0.34 \mathrm{mg} \mathrm{l}^{-1}$ ) and mean TN reaching $7.5 \mathrm{mg} \mathrm{l}^{-1}$ (range $=2.23-16.04 \mathrm{mg}^{-1}$ ). Although governmental routine monitoring frequently reports the presence of organic contaminants (Cho et al., 2014), concentrations were found to be under detection limit based on the water sampling of September 2015. A PCA was conducted to explore site distribution based on surface water characteristics (Fig. 2), and showed distinct differences among sampling sites. The PCA biplot explained $69 \%$ of the variance (PCA axis 1 contributed 50\% and PCA axis 2, 19\%). The ordination indicates that Dalseo, Keumho, Soyo and Daejeon cluster on the right-hand side of the biplot. Within the 16 sites, these four sites have higher concentrations of $\mathrm{Ni} / \mathrm{Cu}$ or $\mathrm{Zn}$ and nutrients (TN), along with high conductivity, TDS, $\mathrm{BOD}_{5}$, and coliforms, and were therefore classified as "severely impacted". The 12 other sites occupy the left-hand side of the biplot and cluster close to the center. These sites generally have high nutrient concentrations potentially reflecting eutrophication, but were classified here as "less-impacted" because chemical analyses did not reveal any metal contamination. Dalseo, Keumho, Soyo and Daejeon cluster apart from the other sites mostly due to high metal concentrations at these sites (values were under detection limits at the other sites). However, a PCA conducted without metal data (results not presented) also revealed that these four sites stood apart from the others, principally along a gradient of total nitrogen, coliforms, $\mathrm{BOD}_{5}$, and conductivity. In general, based on the available water quality parameters, the sampling sites on the Nakdong and Han rivers appeared to be more impacted than the sites on the Yeongsan and Geum rivers.

\subsection{Diatom assemblage structure}

A total of 65 diatom species were observed in this study, but only 23 were included in the ordination based on the $1 \%$ relative abundance criterion. This is based on the results of Lavoie et al. (2009), which show that deleting rare species that occur with relative abundances of $<2 \%$ does not affect the general outcome of site distribution using ordinations. However, because only 65 species were observed in the present study, a more conservative criterion of $1 \%$ was used. PCA analysis performed on the diatom relative abundance data showed that Dalseo, GJ-2, Soyo and Daejeon clustered on the right-hand side of the ordination, with site distribution mainly structured by the diatoms Eolimna minima, Gomphonema parvulum, Nitzschia frustulum, Nitzschia inconspicua and Nitzschia palea (Fig. 3). Ayang and Keumho clustered at the top of the bi-plot and their position was mainly driven by Achnanthidium minutissimum and Cocconeis placentula. The other ten sites were mainly positioned on the left of the graph and showed higher relative abundances of Cymatopleura solea, Fragilariforma virescens, Luticola muticopsis, Navicula capitatoradiata, Navicula gregaria, Navicula rostellata, Pinnularia viridis andSurirella linearis. A dashed line was a posteriori arbitrarily added to the graph to separate the sites based on their distribution: most severely impacted sites mainly reflecting metal contamination, versus less-impacted sites (but still showing relatively high nutrient concentrations). The diatom-based PCA biplot explained $45 \%$ of the variance in site distribution (PCA axis 1 contributed 31\% and PCA axis $2,14 \%)$.

\subsection{Comparing PCAs: one-time water chemistry versus diatom assemblages}

Comparing site distribution based on physico-chemical variables versus diatom assemblages revealed similarities in overall water quality assessment: Dalseo, Soyo and Daejeon clustered apart from the other sites in both approaches, suggesting more contaminated environments. The diatom assemblage structure observed at GJ-2 was similar to the assemblages found at the three above-mentioned sites, which suggests that this site may also have impacted conditions. Keumho, classified as severely impacted based on chemistry, also clustered apart from the sites showing less impacted conditions. Ayang may also be severely impacted as it clustered with Keumho and was apart from the other sites. Overall, the two PCAs conducted using chemistry or diatoms separated the sites into two main groups that may be coarsely characterized as "severely impacted" and "less-impacted". However, the diatom-based PCA suggests that, in addition to Dalseo, Keumho, Soyo and Daejeon, the assemblages from Ayang and GJ-2 may also reflect impacted conditions. This situation may represent a good example in which the biota provides additional information on water quality status beyond traditional chemistry measurements. The fact that Ayang and GJ-2 suggest more impacted conditions based on diatom assemblages compared to chemistry-based assessment may result from temporally fluctuating contamination (e.g., episodic releases). The timing of spot sampling for water chemistry analyses may not correspond to the release of pollutants, such as metals.

\subsection{Non-taxonomical diatom-based metrics}

\subsubsection{Cell density}

Diatom frustule density was estimated at each of the 16 sites (Fig. 4). Lower diatom cell densities (120,000-180,000 frustules $\mathrm{cm}^{-2}$ ) were observed at Keumho, Gwangjugong, Gwangju-1, Soyo and Daejeon, while relatively higher frustule densities $\left(300,000-570000 \mathrm{~cm}^{-2}\right)$ were estimated at the 11 other sites. Despite the observed differences, it is important to keep in mind for data interpretation that the cell densities are nevertheless within the same order of magnitude. Soyo, Daejeon and Keumho have water chemistry profiles reflecting higher degradation levels, which may in part explain the lower cell densities in the samples. Lower diatom cell counts have been reported in metal-contaminated water bodies in numerous studies (Gold et al., 2002; Duong et al., 2010), and namely in India under $\mathrm{Cu}, \mathrm{Zn}$ and $\mathrm{Pb}$ stress in the river Ganges (Pandey et al., 2014), and under $\mathrm{Cu}$ and $\mathrm{Zn}$ contamination in mining areas of Rajasthan (Pandey and Bergey, 2016). However, Gwangjugong and Gwangju-1, which also show lower cell densities, did not cluster with the most impacted sites based on water chemistry. These results suggest that cell density alone may not always provide a good appreciation of water quality. Indeed, periphyton biomass (including diatoms) is influenced by numerous other factors, such as water velocity (Villeneuve et al., 2011) and grazing pressure (Guasch et al., 2016), and these may have a greater effect on cell density than water chemistry at certain sites. Furthermore, a high diatom cell count does not necessarily reflect good conditions (as observed in the sample collected at Ayang), as it could also be the result of nutrient enrichment. While this metric is interesting, particularly in the context of metallic or organic contamination, it should be used as complementary information with other biological descriptors. Comparing diatom cell densities with soft-algae densities might also be a good metric to consider, as the changes in the proportions of algal groups may provide valuable additional information on the ecosystem structure and function. For example, the fact that diatoms represent a high-quality food resource for invertebrates and their reestablishment after a distur- 
Table 1

Physical and chemical variables measured in the surface water of the 16 sites. nd $=$ under detection limit.

\begin{tabular}{|c|c|c|c|c|c|c|c|c|c|c|c|c|c|}
\hline River & Site & $\begin{array}{l}\text { DO mg } \\
1^{-1}\end{array}$ & $\begin{array}{l}\mathrm{BOD}_{5} \mathrm{mg} \\
1^{-1}\end{array}$ & $\begin{array}{l}\text { Coli CFU } \\
\mathrm{ml}^{-1}\end{array}$ & $\begin{array}{l}\text { Temp } \\
{ }^{\circ} \mathrm{C}\end{array}$ & $\begin{array}{l}\text { Cond } \\
\mu \mathrm{S} \mathrm{cm}^{-1}\end{array}$ & $\mathrm{pH}$ & $\begin{array}{l}\mathrm{TN} \text { mg } \\
1^{-1}\end{array}$ & $\begin{array}{l}\text { TP mg } \\
1^{-1}\end{array}$ & $\begin{array}{l}\text { TDS mg } \\
1^{-1}\end{array}$ & $\begin{array}{l}\text { Cu mg } \\
1^{-1}\end{array}$ & $\begin{array}{l}\mathrm{Ni} \mathrm{mg} \\
\mathrm{l}^{-1}\end{array}$ & $\begin{array}{l}\mathrm{Zn} \mathrm{mg} \\
1^{-1}\end{array}$ \\
\hline \multirow[t]{3}{*}{ Nakdong } & Ayang & 11.44 & 1.51 & 2 & 23.4 & 470 & 8.8 & 5.96 & 0.028 & 380 & nd & nd & 0.075 \\
\hline & Dalseo & 11.54 & 1.93 & 10 & 27.3 & 2895 & 7.67 & 10.04 & 0.084 & 1704 & 0.029 & 0.068 & 0.017 \\
\hline & Keumho & 11.55 & 2.08 & 9 & 26.4 & 2580 & 8.16 & 10.93 & 0.112 & 2180 & 0.048 & 0.045 & 0.034 \\
\hline \multirow[t]{4}{*}{ Yeongsan } & Gwangjugong & 11.1 & 2.08 & 72 & 22.1 & 309 & 8.02 & 3.96 & 0.111 & 184 & nd & nd & 0.071 \\
\hline & Gwangju-1 & 11.65 & 1.43 & 6 & 23.4 & 204 & 9.25 & 2.23 & 0.013 & 190 & nd & nd & 0.071 \\
\hline & GJ-2 & 11.75 & 1.49 & 5 & 22.8 & 321 & 7.87 & 3.91 & 0.111 & 242 & nd & nd & 0.05 \\
\hline & PD-1 & 11.77 & 1.66 & 19 & 20.6 & 170 & 7.67 & 5.51 & 0.115 & 276 & nd & nd & 0.07 \\
\hline \multirow[t]{7}{*}{ Geum } & Ohryang & 11.75 & 0.71 & 16 & 23.4 & 439 & 7.6 & 6.22 & 0.34 & 282 & nd & nd & 0.09 \\
\hline & Bangchuk & 11.12 & 2.53 & 8 & 23.2 & 438 & 8.14 & 16.04 & 0.194 & 40 & nd & nd & 0.062 \\
\hline & Masan & 11.3 & 3.14 & 15 & 23.3 & 321 & 8.38 & 7.23 & 0.297 & 302 & nd & nd & 0.057 \\
\hline & Sucheol & 11.48 & 1.44 & 5 & 22.4 & 362 & 8.74 & 7.14 & 0.304 & 302 & nd & nd & 0.053 \\
\hline & Miho-5 & 11.45 & 2.63 & 15 & 21.5 & 659 & 7.45 & 7 & 0.12 & 454 & nd & nd & 0.081 \\
\hline & Miho-8 & 11.44 & 1.22 & 4 & 24.0 & 482 & 8.15 & 3.83 & 0.12 & 268 & nd & nd & 0.079 \\
\hline & Miho-7 & 11.33 & 1.25 & 46 & 21.8 & 505 & 7.72 & 5.44 & 0.111 & 342 & 0.004 & nd & 0.075 \\
\hline \multirow[t]{2}{*}{ Han } & Soyo & 10.34 & 9.25 & 240 & 27.6 & 4007 & 7.72 & 14.19 & 0.098 & 2132 & nd & 0.021 & 0.3 \\
\hline & Daejeon & 10.86 & 3.43 & 64 & 24.7 & 2579 & 8.35 & 9.88 & 0.097 & 898 & 0.043 & 0.016 & 0.44 \\
\hline
\end{tabular}




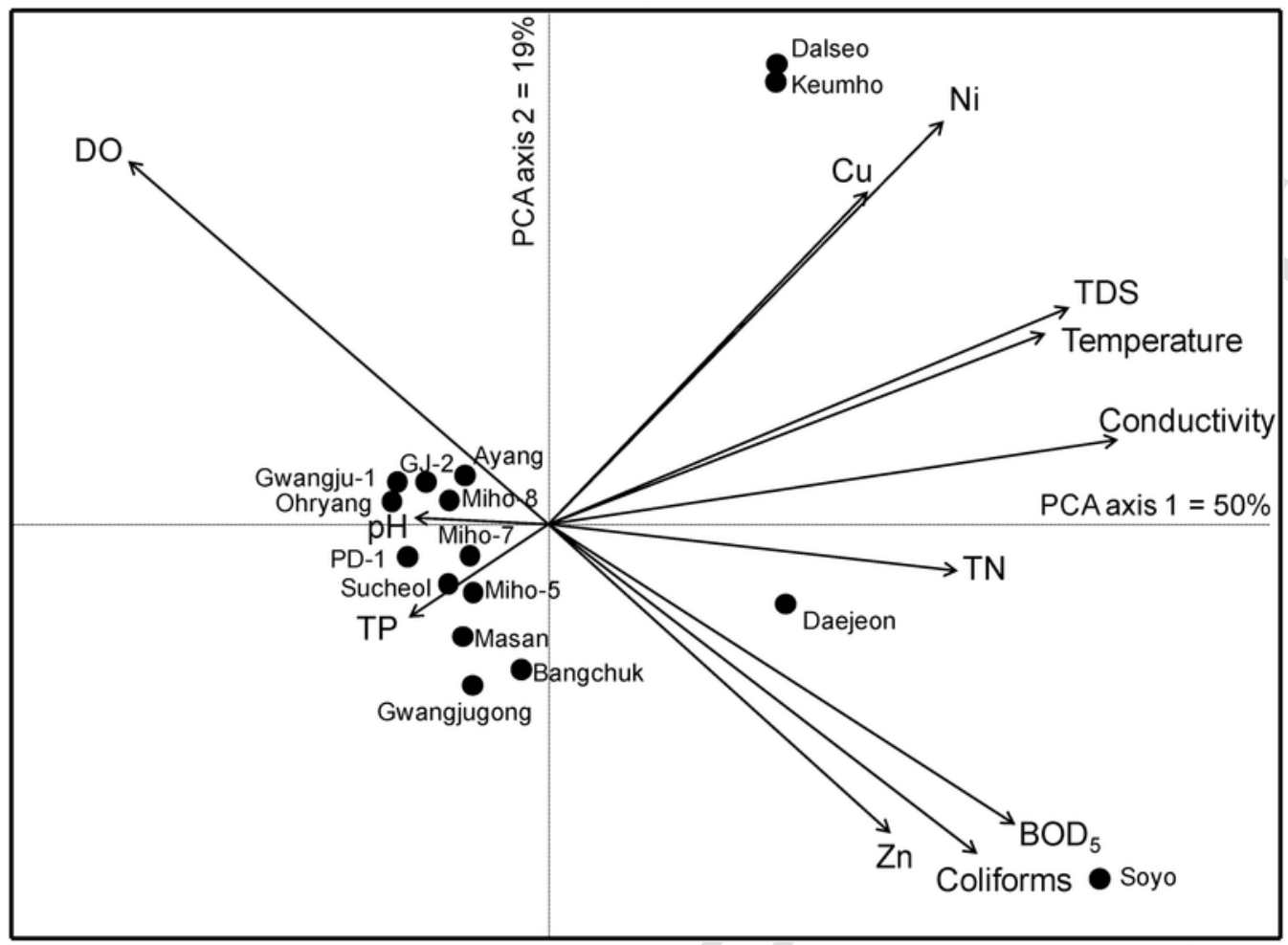

Fig. 2. Principal component analysis showing site distribution based on physico-chemical parameters. Axes 1 and 2 combined explain $69 \%$ of the variance.

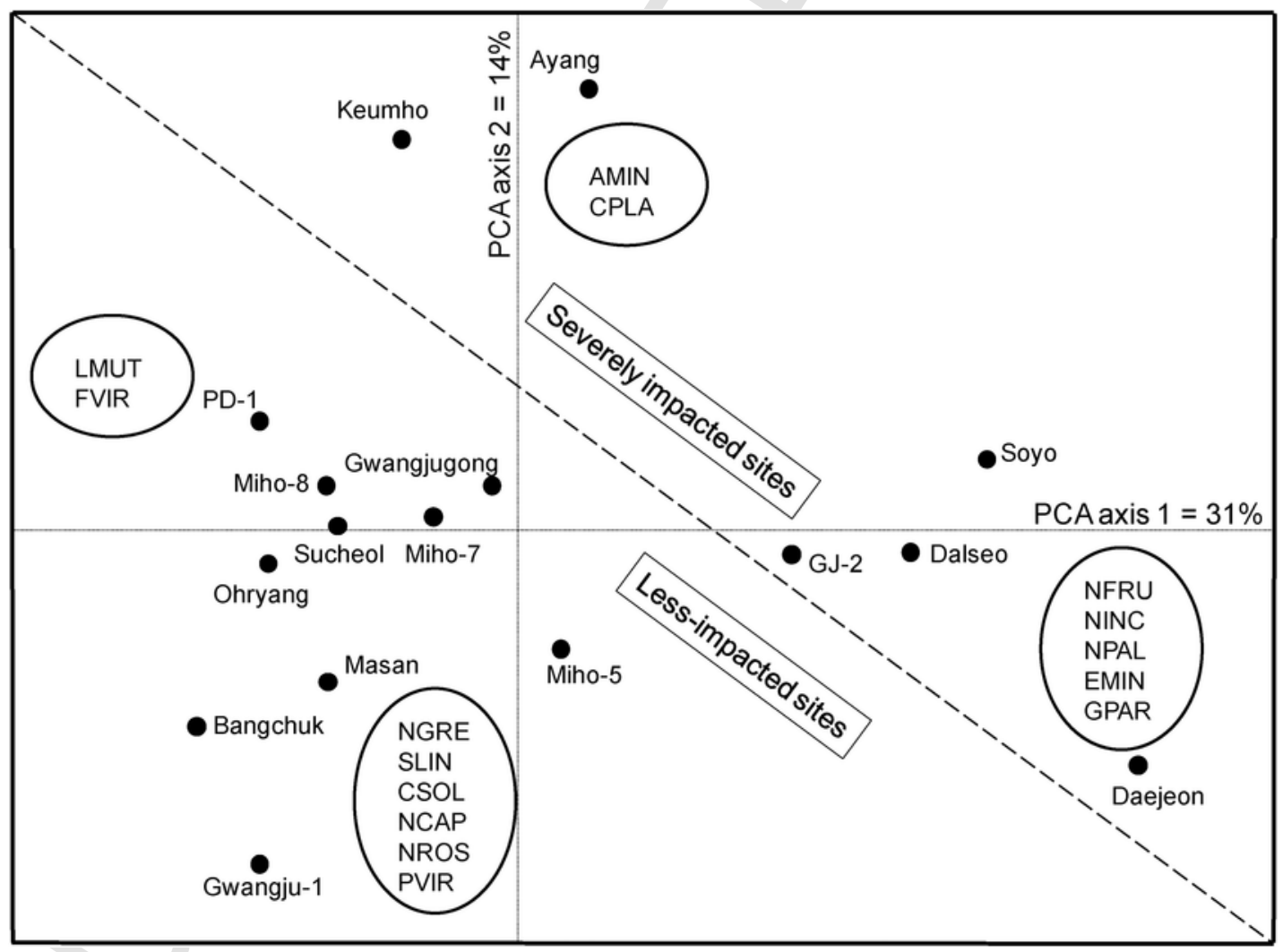

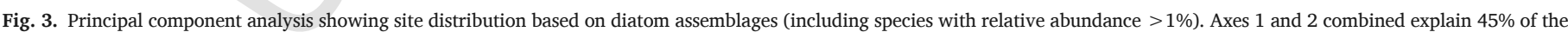

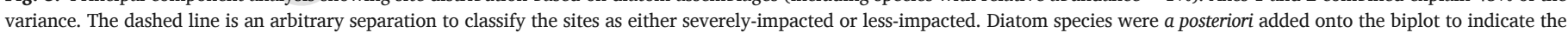

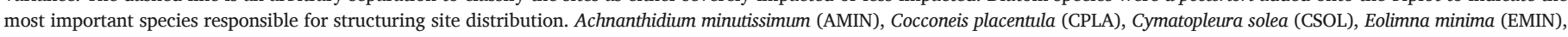

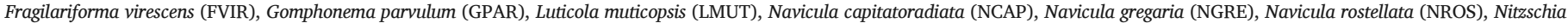
frustulum (NFRU), Nitzschia inconspicua (NINC), Nitzschia palea (NPAL), Pinnularia viridis (PVIR), Surirella linearis (SLIN). 


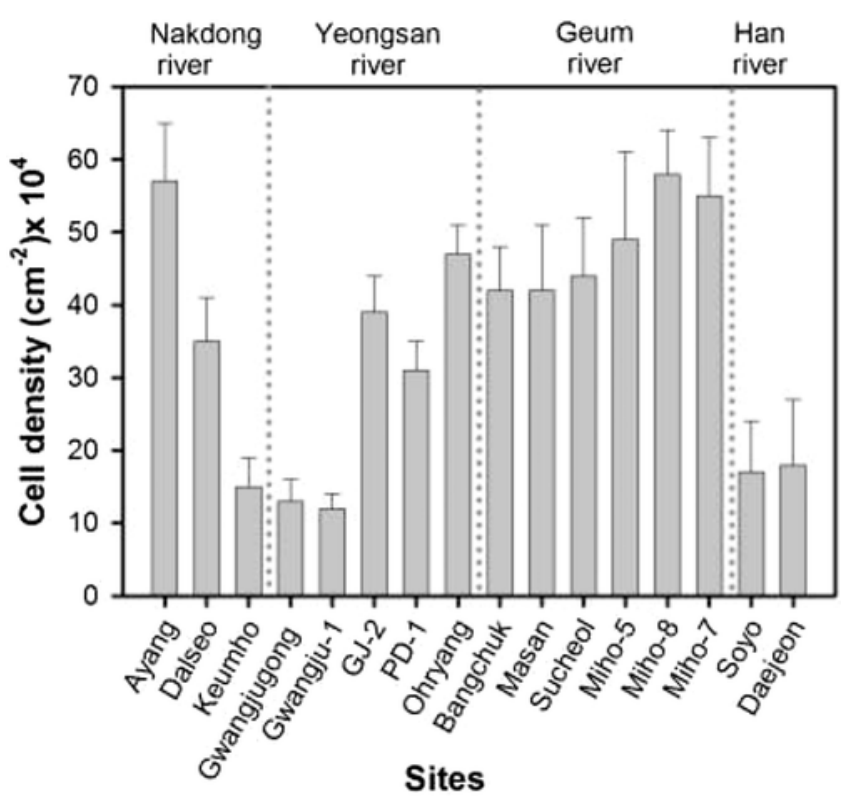

Fig. 4. Diatom cell density (Mean $\pm \mathrm{SE} ; \mathrm{n}=3$ ) in samples collected at the 16 sites.

bance, in comparison with other algal groups (Steinman and McIntire, 1990; Morin et al., 2010; Arini et al., 2013), may be a critical factor in the recovery rates of consumers.

\subsubsection{Periphytic diatom richness and diversity}

Biodiversity descriptors such as Shannon's diversity index and species richness are regularly used as tools for investigating the biological integrity status of an ecosystem. For example, Verb and Vis (2000) reported significantly lower species richness and Shannon's diversity index at acid mine drainage sites than at reclaimed sites, while Barral-Fraga et al. (2016) reported lower values for these metrics in diatom-dominated biofilms contaminated with arsenic. Similarly, the diatom assemblages collected in the present study showed lower species richness (10-23) and/or Shannon's diversity index (1.6-2.0) at polluted sites Ayang, Dalseo, Keumho, GJ-2, Soyo and Daejeon, but also at sites Gwangjugong and Gwangju-1. PD-1, Ohryang, Bangchuk, Masan, Sucheol, Miho-5, Miho-8 and Miho-7 showed higher species richness (30-50) and Shannon diversity index (2.6-3.8) (Fig. 5). As a general trend, the sites clustered on the right-hand side of the PCA (Fig. 2) with more severely degraded conditions were associated with lower richness and diversity. However, these metrics also showed lower values for certain sites that were not considered as impacted, based on chemical analyses. This lack of concordance at some sites may suggest that the available one-time physico-chemical data do not reflect the temporally fluctuating nature of these waters and that diatom diversity brings additional insight on the environmental integrity of the sites. It may also indicate that diversity and richness are not always good proxies of water quality, and perhaps should not be used alone as bioindicators. This aspect is discussed in Blanco et al. (2012), where diversity indices are reported to generally exhibit poor linear correlations with environmental factors indicating ecological status. Furthermore, sampling effort or sample size may strongly affect richness and diversity values, thus influencing water quality status comparisons. However, this does not represent an issue in the present study as the same protocol was used for all samples ( $\sim 500$ frustules per sample).

\subsubsection{Cell size}

It has been shown in numerous studies that small-sized species tend to dominate in metal-contaminated environments (Ivorra et al., 1999; Morin et al., 2008, 2012; Tlili et al., 2011; Barral-Fraga et al., 2016).

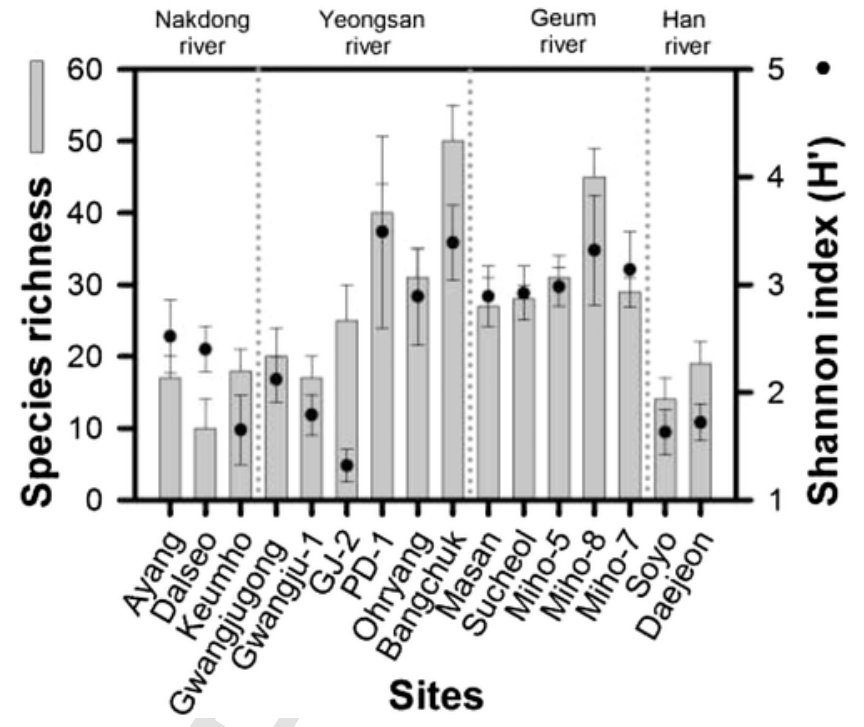

Fig. 5. Species richness and Shannon diversity index values (Mean \pm SE; $n=3$ ) of diatom assemblages collected at the 16 sites.

Decrease in diatom frustule size within a given species has also been reported as a response to metal stress. For example, Cattaneo et al. (2004) reported that metal contamination within sediment cores from a Canadian lake was responsible for size reduction. Similarly, Luís et al. (2011) reported size decline in Brachysira vitrea frustules at metal-contaminated sites of Corona stream, Portugal. In the present investigation, the four sites considered as the most impacted based on physico-chemical parameters (Dalseo, Soyo, Daejeon, Keumho) were characterized by a dominance of small adnate diatom species (Fig. 6). Ayang and GJ-2 also showed high abundances of small-sized diatoms, which did not seem to reflect metallic contamination based on the available data. On the other hand, the ordination conducted on diatom assemblages (PCA) indicated severely impacted conditions for these two sites (Fig. 3) that may not have been noticed based solely on the available chemistry data. It is also possible that factors other than contamination favored small diatoms, including grazing and colonization phase following a physical disturbance. Gwangjugong, PD-1, Masan, and Miho-5 showed high proportions of small-sized diatoms, although neither of these sites was considered as severely impacted based on chemistry or diatom assemblage data. This suggests that cell-size alone may not provide a complete picture of an ecosystem's health status. However, as a general trend, the sites that were considered less contaminated showed a dominance of intermediate and large diatom species, reaching up to more than $50 \%$ of the assemblage.

\subsubsection{Diatom cell health status}

Investigation of live and dead diatoms in the assemblage may provide additional environmental information (Cox, 1998; Stevenson and Pan, 1999; Gillett et al., 2011). Wood et al. (2014, 2016) reported health status of diatoms (intact vs. unhealthy cells) as a sensitive and rapid method for assessing herbicide toxicity. Gillett et al. (2009) argued that conventional diatom cell count methods provide taxonomical confidence while the live diatom count offers better ecological reliability. In a general biomonitoring perspective, both approaches are valuable and complementary. Among the 16 sites examined, Gwangju-1, PD-1, Ohryang, Bangchuk, Masan, Sucheol, Miho-5, Miho-7 and Miho-8 showed a predominance (40-50\%) of live frustules (Fig. 7), while percent unhealthy frustules showed higher values $(>40 \%)$ at Dalseo and GJ-2. Percent dead frustules in the diatom assemblages showed higher values (40-65\%) at Ayang, Gwangjugong, Soyo and Daejeon. As a general trend, the less-impacted sites clustering on the left-hand side 

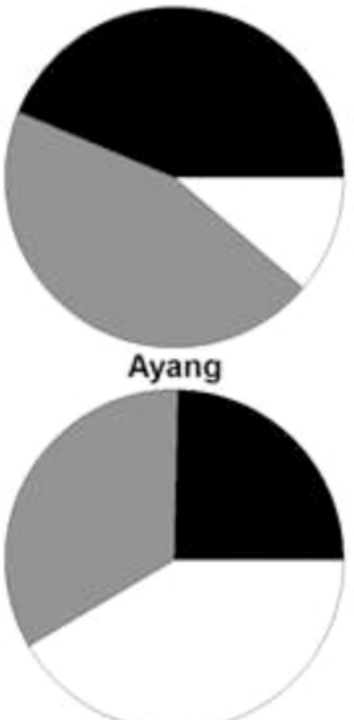

Gwangju-1
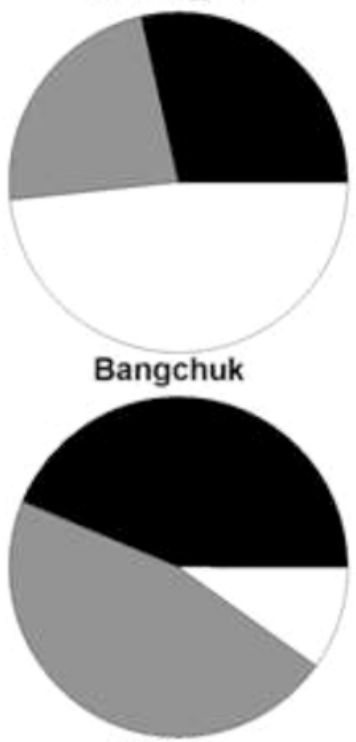

Miho-8

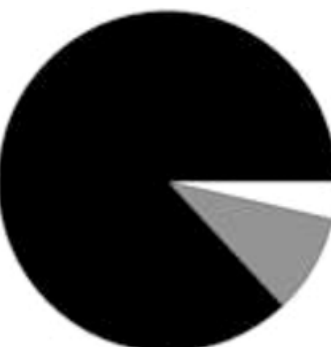

Dalseo

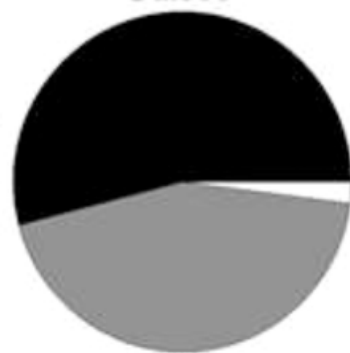

GJ-2
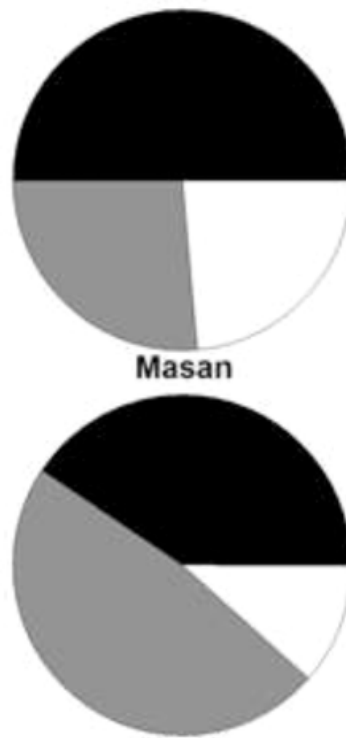

Miho-7

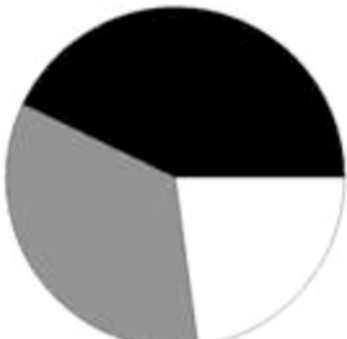

Keumho

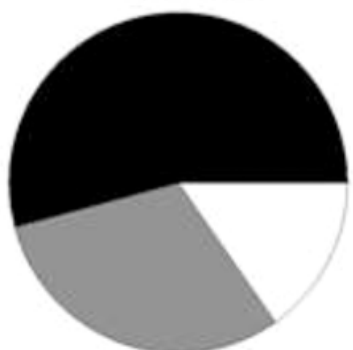

PD-1

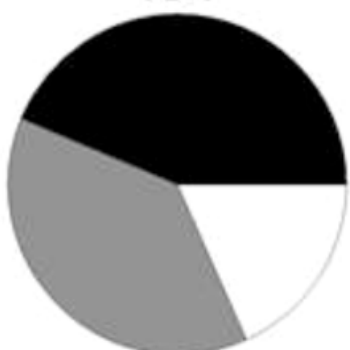

Sucheol

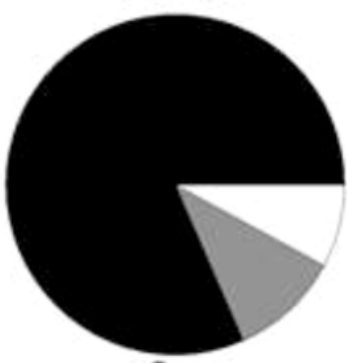

Soyo

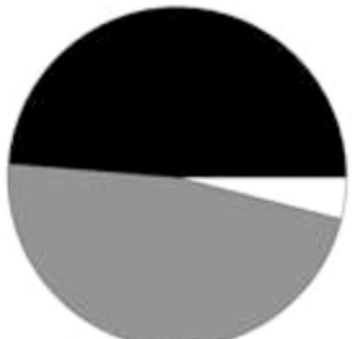

Gwangjugong

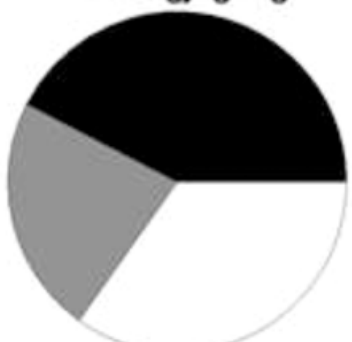

Ohryang

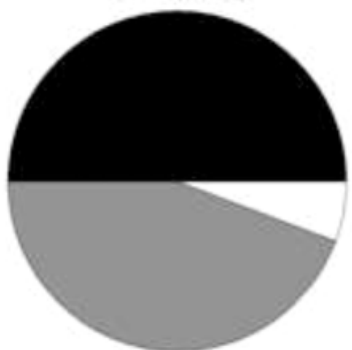

Miho-5

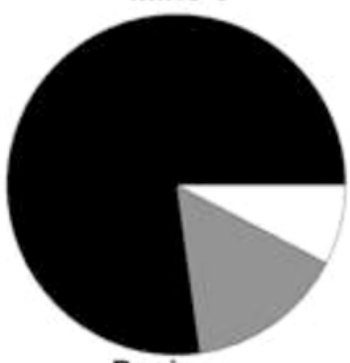

Daejeon

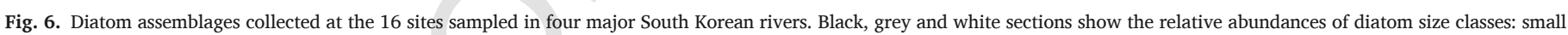
$\left(<400 \mu \mathrm{m}^{3}\right)$, intermediate $\left(400-4000 \mu \mathrm{m}^{3}\right)$, and large $\left(>4000 \mu \mathrm{m}^{3}\right)$.

of the diatom-based ordination (Fig. 3) also showed higher proportions of live diatoms, suggesting healthier conditions. This trend was not as clear when relating diatom health status and chemistry data, indicating that diatoms may have responded to other stresses or that there is a time lag between water quality change and cell degradation. It is also possible that the presence of dead cells is independent of site degradation. For example, very low water velocity may favor dead cell deposition. However, all sites sampled in this study were characterized by relatively low flow, which suggests that the variation in diatom health status among sites are more likely to reflect water quality than differences in dead cell accumulation.

\subsubsection{Lipid bodies}

Lipid bodies constitute energy reserves in algae. Under stressed conditions (e.g. nutrient depletion, metal contamination, excess light), these lipid droplets are reported to increase in number and size (Pandey et al., 2015; Yang et al., 2013; Liang et al., 2015; d'Ippolito et al., 2015). The number of LBs and their respective diameters were examined in six commonly occurring diatom species at the 16 study sites ( N. gregaria, $N$. capitatoradiata, $N$. inconspicua, $N$. rostellata, $N$. frustulum and $N$. palea) (Fig. 8). Table 2a presents the range in $\%$ biovolume contribution of lipid bodies to total cell volume at each site, while Table $2 \mathrm{~b}$ presents a detailed summary of the LB's characteristics for the six most common species in which LBs were counted and measured. Looking at the sites individually, the proportion of LBs relative to cell biovolume was higher for Soyo, Daejeon, Dalseo and Keumho (Table 2a). A marked difference in LBs was observed when comparing contaminated sites versus less-contaminated sites (based on physico-chemistry data) where more impacted conditions seemed to have stimulated LB production. In the present study, lipid body analysis suggests that di- 


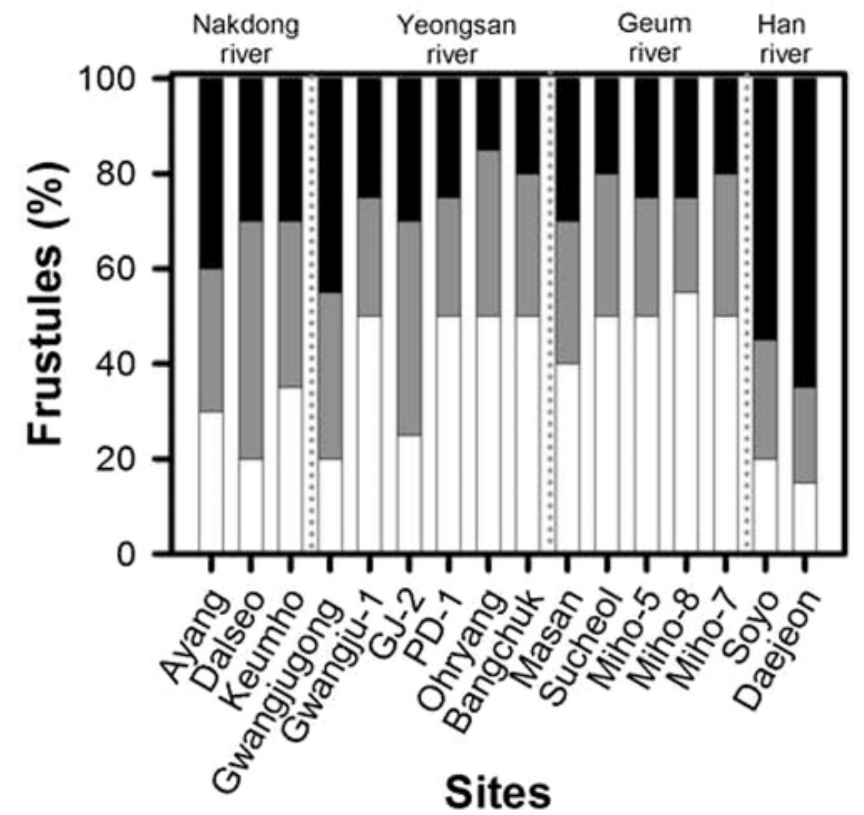

$\square$ Live

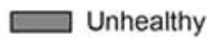

Dead

Fig. 7. Relative contribution of live frustules, unhealthy frustules, and dead frustules in the samples collected at the 16 sites

atoms responded to a metal stress, as LBs were observed with higher abundances and larger sizes at the sites showing the highest concentrations of metals. However, it is important to note that other environmental stresses may have influenced LB production and that this was not assessed in this study. LB stimulation by metal contamination has been widely reported (Einicker-Lamas et al., 2002; Liu et al., 2008; Wang et al., 2009; Pillai et al., 2014; Pandey et al., 2015, 2016; Gautam et al., 2017). LBs are promising biomarkers of stress although more research is required to define their variability under various natural conditions for optimal use in a bioassessment perspective. The approach is relatively easy, as taxonomical skills are not required (all diatom species are likely to produce LBs in larger number and size under stressed conditions).

\subsubsection{Deformities}

Numerous studies relate deformities with environmental disturbances (see review in Falasco et al., 2009a), particularly in metal-contaminated conditions (Morin et al., 2012; Lavoie et al., 2012; Leguay et al., 2016; Pandey and Bergey, 2016). In the present study, 13 species out of the total 65 species identified showed deformities in their frustules (Fig. 9). Deformed frustules were encountered in small (Achnanthes exigua, E. minima, Fragilaria capucina, G. parvulum, Planothidium frequentissimum and Staurosira sp.) as well as in larger diatom species ( $C$. placentula, Cymbella turgidula, Diatoma vulgaris, Tabularia fasciculata and Ulnaria ulna). Mean percent deformities were estimated in each of the 16 samples (Fig. 10). Ayang, Dalseo, GJ-2, Soyo and Daejeon showed relatively higher percentages of teratologies $(2,2,2,6$ and $8 \%$, respectively) compared with the other sites $(<0.5 \%)$. According to Morin et al. (2008) and Arini et al. (2012), naturally occurring deformities in diatom assemblages are usually rare (below 1\%). The frequencies of teratologies observed in the present study therefore suggest a response to a stress. While Dalseo, Soyo and Daejeon showed higher concentrations of metals (Table 1, Fig. 2), the causes of deformities at Ayang and GJ-2 are unclear. It may be a response to unidentified environmental variables or it could indicate that chemistry values available for this study did not reflect the actual, prevalent environmental conditions due to temporal fluctuation. Overall, abnormal valve outline was the most widely occurring aberration and was found in A. exigua, C. placentula, C. turgidula, D. vulgaris, E. minima, F. capucina, G. parvulum, $P$. frequentissimum, Staurosira construens, T. fasciculata and U. ulna. However, the deformity in the striation pattern and mixed deformity showed the highest proportion, particularly at sites Soyo and Daejeon (Fig. 11). Deformity types may be metal specific. For example, Pandey et al. (2014, 2015) also reported prevalence of abnormal striations and mixed defor-
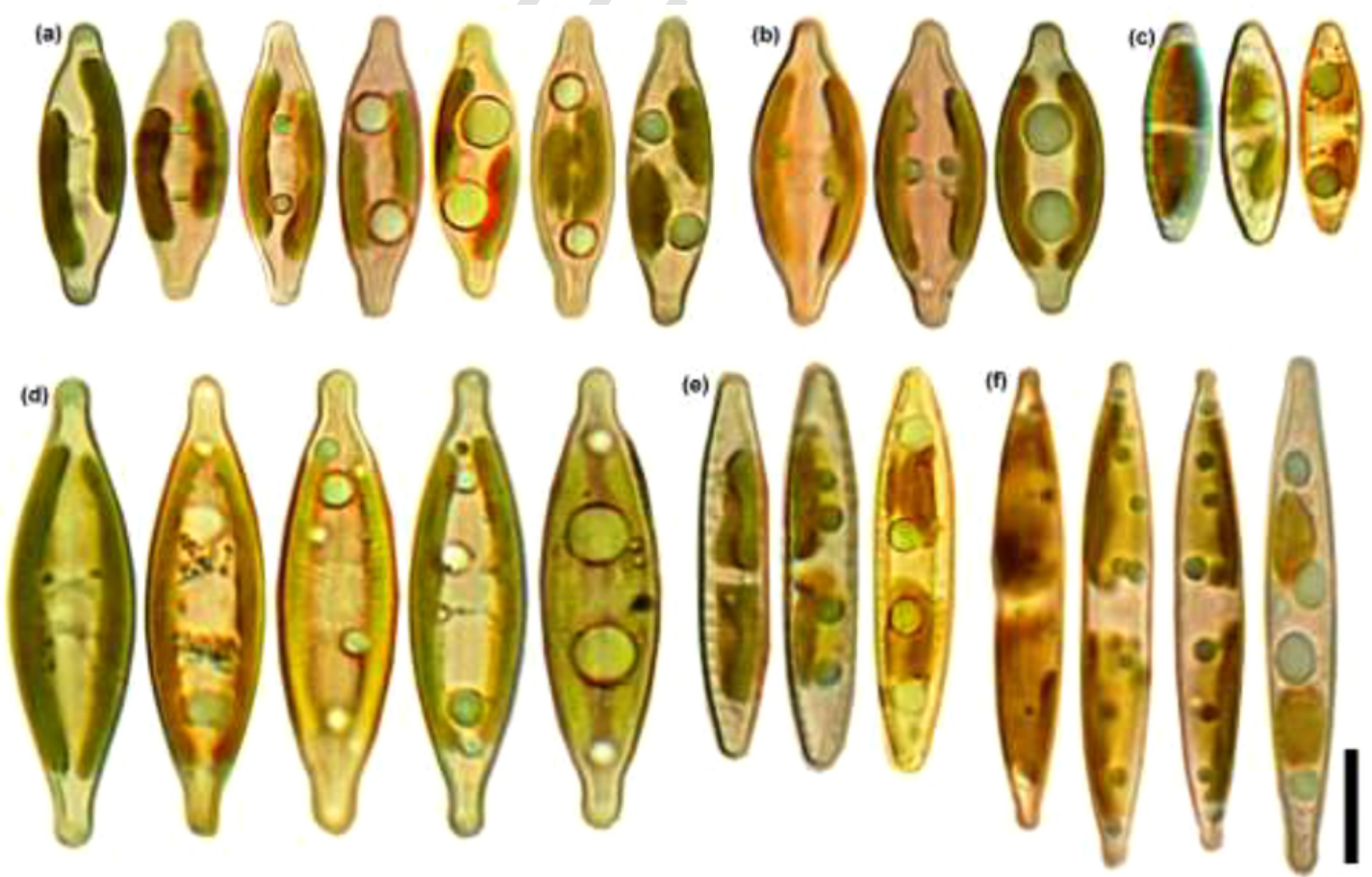

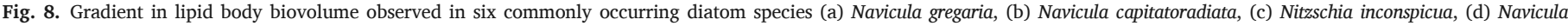
rostellata, (e) Nitzschia frustulum and (f) Nitzschia palea. Scale bar $=7 \mu \mathrm{m}$. 
Table 2a

Overall range in\% biovolume contribution of lipid bodies to total cell biovolume at each site.

\begin{tabular}{|c|c|c|c|c|c|c|c|c|c|c|c|c|c|c|c|}
\hline Rivers & Nakdon & & & Yeongsan & & & 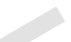 & Geum & 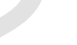 & & & & & & Han \\
\hline Sites & Ayang & Dalseo & Keumho & Gwangjugong & Gwangju-1 & GJ-2 & PD-1 & Ohryang & Masan & Sucheol & Bangchuk & Miho-5 & Miho-8 & Miho-7 & Soyc \\
\hline $\begin{array}{l}\% \\
\text { biovolume } \\
\text { contribution } \\
\text { of LBs to } \\
\text { total cell } \\
\text { volume }\end{array}$ & $4-7$ & $8-28$ & $5-40$ & $2-5$ & $4-7$ & $2-6$ & $1-3$ & $2-5$ & $2-7$ & $1-5$ & $4-7$ & $2-6$ & $4-7$ & $2-6$ & $5-6 c$ \\
\hline
\end{tabular}


Table 2b

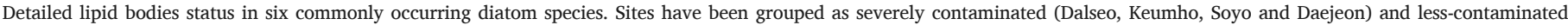
waters bodies (other 12 sites) based on the chemistry-based ordination.

\begin{tabular}{|c|c|c|c|c|c|c|}
\hline & \multicolumn{2}{|c|}{ Number of lipid bodies } & \multicolumn{2}{|c|}{ Diameter $(\mu \mathrm{m})$ of lipid bodies } & \multicolumn{2}{|c|}{$\begin{array}{l}\% \text { biovolume contribution of lipid bodies to total } \\
\text { cell volume }\end{array}$} \\
\hline & $\begin{array}{l}\text { Less contaminated } \\
\text { sites }\end{array}$ & $\begin{array}{l}\text { Contaminated } \\
\text { sites }\end{array}$ & $\begin{array}{l}\text { Less contaminated } \\
\text { sites }\end{array}$ & $\begin{array}{l}\text { Contaminated } \\
\text { sites }\end{array}$ & $\begin{array}{l}\text { Less contaminated } \\
\text { sites }\end{array}$ & $\begin{array}{l}\text { Contaminated } \\
\text { sites }\end{array}$ \\
\hline Navicula gregaria & $0-2$ & $2-4$ & $0.0-0.5$ & $0.5-3.0$ & $4-7$ & $20-60$ \\
\hline $\begin{array}{l}\text { Navicula } \\
\text { capitatoradiata }\end{array}$ & $0-2$ & $2-4$ & $0.0-3.0$ & $0.2-3.0$ & $2-6$ & $15-60$ \\
\hline Navicula rostellata & $0-2$ & $2-6$ & $0.0-0.5$ & $0-2.5$ & $2-5$ & $5-20$ \\
\hline Nitzschia inconspicua & $0-4$ & $4-6$ & $0.0-0.2$ & $0-3.2$ & $1-3$ & $6-35$ \\
\hline Nitzschia frustulum & $0-4$ & $0-4$ & $0.0-0.3$ & $0.5-2.0$ & $2-7$ & $10-20$ \\
\hline Nitzschia palea & $0-2$ & $2-8$ & $0.0-0.4$ & $0.5-2.0$ & $1-3$ & $8-25$ \\
\hline
\end{tabular}
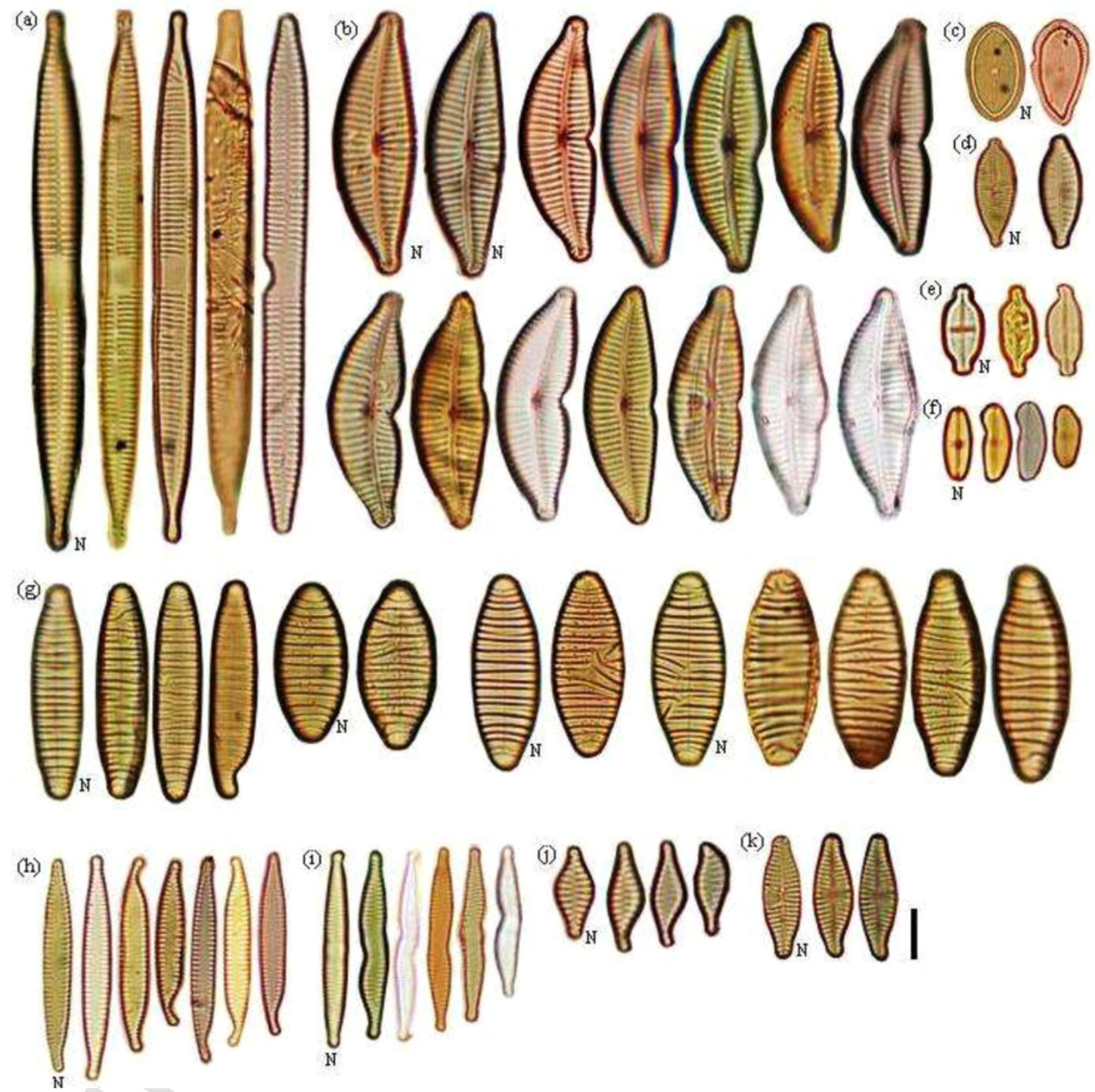

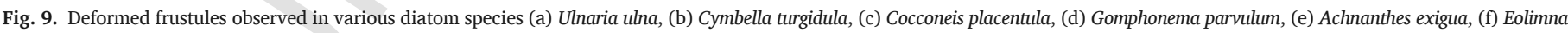

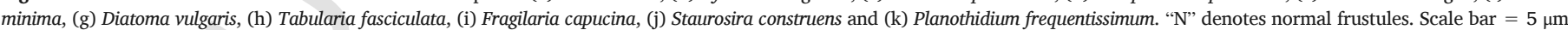

mities under Zn stress in field and laboratory studies. Deformed raphes were rarely observed and found only at a few sites (and only in Navicula recens), while deformed costae were observed only at Miho-8 (and only in $D$. vulgaris).
Numerous studies, including the present investigation, report deformed frustules in adnate and araphid diatoms (Morin et al., 2008; Falasco et al., 2009a,b; Pandey et al., 2014; Leguay et al., 2016; Pandey et al., 2016), which suggests that species belonging to these groups may be more prone to teratologies (also see discussion in Lavoie 


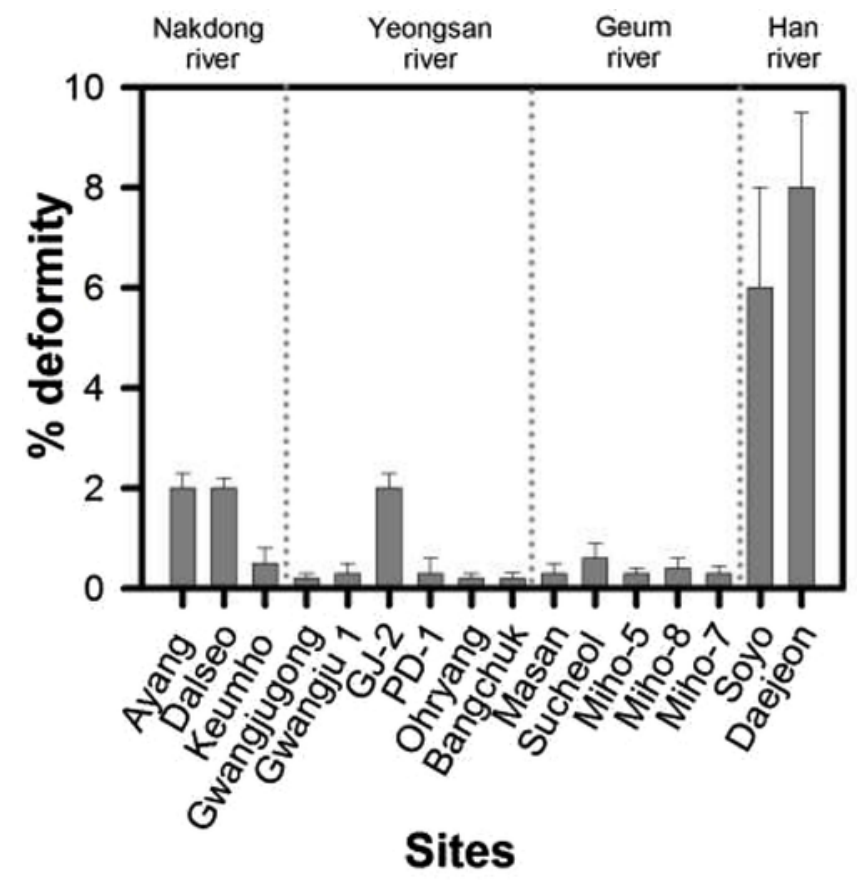

Fig. 10. Occurrence of deformed valves (\% relative abundance, Mean $\pm S E ; n=3$ ) observed in the samples collected at the 16 sites.

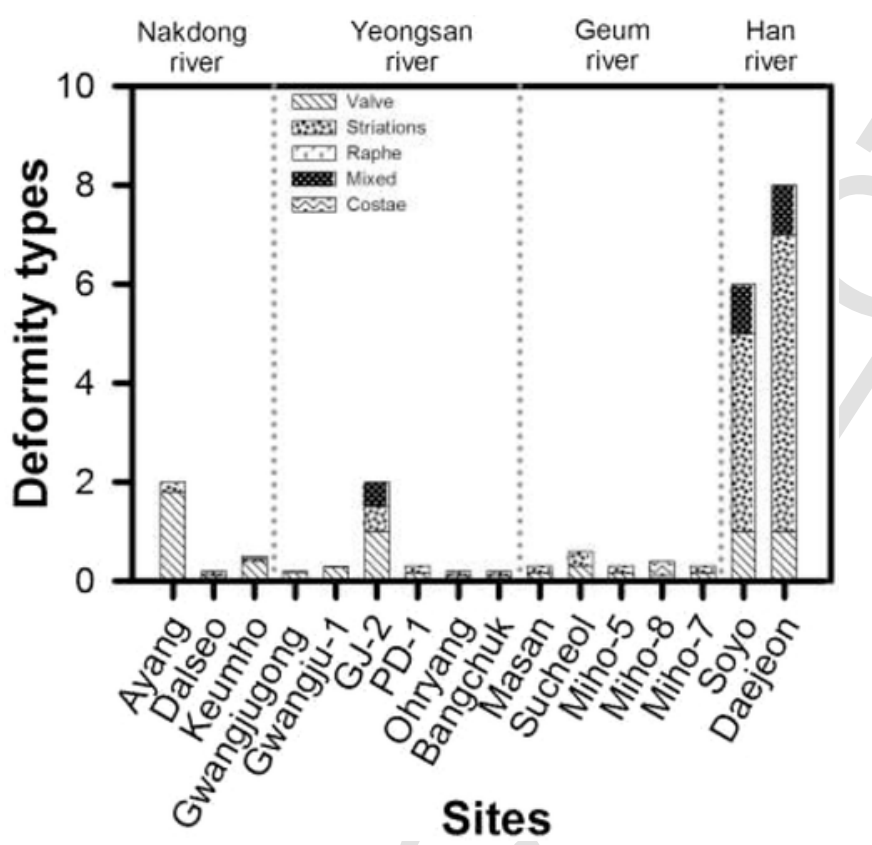

Fig. 11. Relative proportion of each of the five types of deformities observed in the samples collected at the 16 sites.

et al., in press). For example, deformities in A. exigua and C. placentula were frequently observed in this study. Deformed frustules were also noticed in A. minutissimum, C. turgidula, Eolimna subminusula, F. capucina, G. parvulum, P. frequentissimum and U. ulna. These are species that have been regularly reported as presenting aberrations under metal-contaminated environments (Morin et al., 2008; Falasco et al., 2009a,b; Silva et al., 2009; Lavoie et al., 2012; Cantonati et al., 2014; Pandey et al., 2014, 2015, 2016).

\subsubsection{Water quality status as a function of chemistry and diatom-based} metrics

Previous biomonitoring (algae and macroinvertebrates) assessment indicated that many South Korean rivers and streams are severely degraded, with biological conditions that are much worse than their water chemistry suggests (Hwang et al., 2011). Biological metrics do not always correlate well with water chemistry, which is the key argument as to whether biological indicators should be included in routine water quality assessment. The present investigation seems to corroborate this finding; four sites were characterized as more severely impacted based on chemistry data alone (mostly metals, TN, salinity/conductivity and coliforms), while at least two additional sites showed signs of degradation/stress based on multiple diatom-based metrics. Table 3 presents a simplified summary of the water quality status of the 16 sites based on the traditional physico-chemical information, diatom-based ordination, as well as non-taxonomic descriptors. Most importantly, all metrics used agreed on the poor status of the Han River sites (Soyo and Daejeon), and on the lower impacts in the Geum River. Interestingly, along the Nakdong River, the majority of the descriptors put Dalseo and Keumho into the impacted site category. This result is not surprising as the biota generally integrates the environmental conditions well; if the chemistry suggests a degraded system, the organisms should also reflect this reality. On the other hand, chemistry-based assessment is subjected to strong variability and may not always provide a complete and integrated picture of the real conditions (Lavoie et al., 2008a,b). Because biological metrics integrate environmental conditions over time, their response may be delayed compared to chemical analyses. The time frame within which a biotic response will be noted depends on the nature of the biological endpoint assessed (functional versus structural descriptors). This could explain why several metrics calculated for Ayang and GJ-2 suggest a biological impairment, while chemical status does not support such a trend: the diatom assemblages may have responded to one or more stresses that were not assessed here, or it may suggest that the system is in a transitional state towards ecological improvement or degradation. Moreover, following the control of pollution sources, biological metrics may still indicate impairment of water quality and biological integrity due to sediment contamination and its lingering effects. The diagnostic of the status of Gwangjugong and Gwangju- 1 based on the biological descriptors used was not as straightforward because fewer metrics suggested degraded conditions at these sites. The fact that some diatom metrics are more likely to respond quickly to changes in chemistry, in contrast to more resilient indicators such as taxonomical composition, may reflect progressive recovery/degradation of sites. This explanation could be of particular interest at Gwangjugong, where rehabilitation operations have been undertaken. This hypothesis agrees with the results of Arini et al. (2012), who showed that diatom composition failed to demonstrate the recovery, on an intermediate time frame, of a mine-impacted site after remediation practices. Thus, the multiple metrics used could also be informative of the "ecological trajectory" and time-dependent recovery signs, by highlighting the first stages of change in environmental conditions. Ongoing ecosystem recuperation processes could thus be estimated through improvements in early-responding descriptors (eg., teratologies, cell health status, LB content), whereas recovery in diatom taxonomical composition as an endpoint indicator would necessitate a longer time frame. The complementary information provided by non-taxonomical descriptors and biomarkers, combined with classical assemblage structure analyses, possibly makes the overall water quality assessment more powerful and reliable. 
Table 3

Summary of the water quality descriptors used in this study and site classification as "severely impacted (grey)" or "less-impacted (white)" based on each metric.

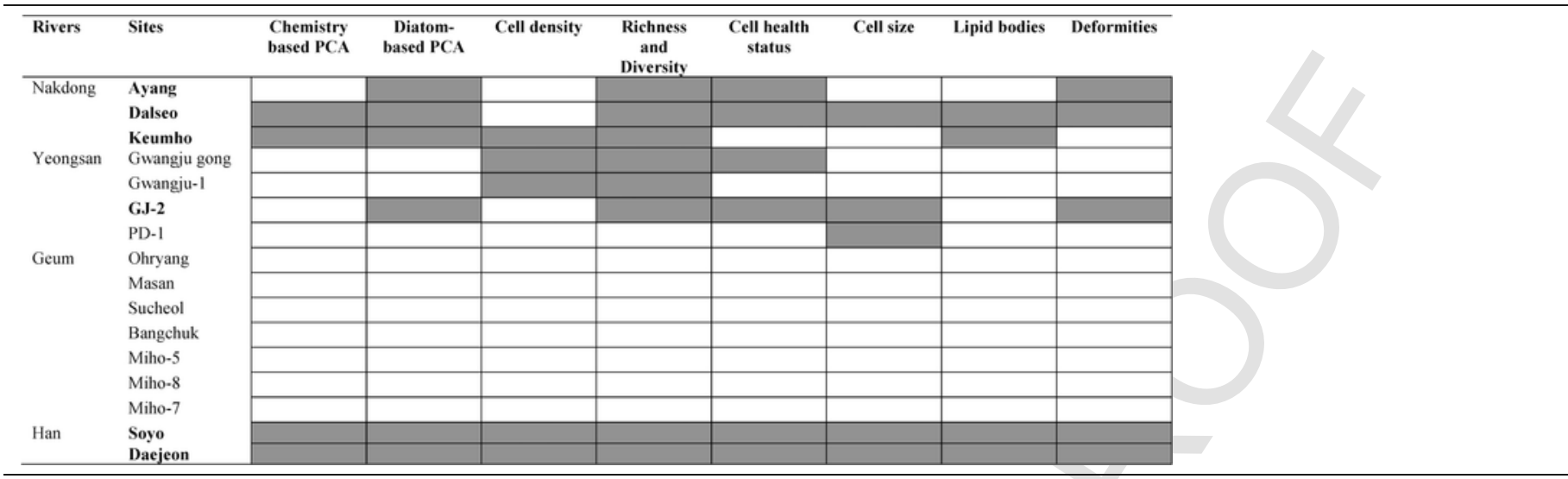

\section{Conclusion}

This study underscores the importance of assessing ecological integrity based on a suite of chemical, physical and biological characteristics of a system. While all metrics examined have the potential to reflect some aspects of biological integrity, the most reliable approach would be to include several descriptors in order to obtain a more complete picture. However, this may not be realistic in a routine monitoring program where time and resources are limited. Diatom assemblage structure, widely used in biomonitoring, allowed for a clear separation of the sites and generally showed good concordance with other metrics. The size and number of lipid bodies and abnormal diatom frustules (teratologies) were also powerful and reliable biomarkers reflecting a response to one or multiple stressors. Supplementary information from cell size and diatom health status provided valuable addition as well. Biomonitoring programs based on multiple descriptors would thus be an interesting and promising approach to develop for the assessment of aquatic ecosystems integrity.

\section{Acknowledgements}

This work was supported by a Post-Doctor Research Program (2015) to L.K. Pandey, through Incheon National University. We are grateful to Dr. J.C. Taylor (North-West University, South Africa) for his generous gift of Pleurax, and to Dr. É. Saulnier-Talbot for providing language revision and comments on an earlier version of the text.

\section{Appendix A. Supplementary data}

Supplementary data associated with this article can be found, in the online version, at http://dx.doi.org/10.1016/j.ecolind.2017.07.043.

\section{References}

Żelazna-Wieczorek, J., Nowicka-Krawczyk, P., 2015. The cascade construction of artificial ponds as a tool for urban stream restoration - the use of benthic diatoms to assess the effects of restoration practices. Sci. Total Environ. 538, 591-599.

Arini, A., Feurtet-Mazel, A., Morin, S., Maury-Brachet, R., Coste, M., Delmas, F., 2012. Remediation of a watershed contaminated by heavy metals: a 2-year field biomonitoring of periphytic biofilms. Sci. Total Environ. 425, 242-253.

Arini, A., Durant, F., Coste, M., Delmas, F., Feurtet-Mazel, A., 2013. Cadmium decontamination and reversal potential of teratological forms of the diatom Planothidium frequentissimum (Bacillariophyceae) after experimental contamination. J. Phycol. 49, 361-370.

Barral-Fraga, L., Morin, S., Rovira, M.D.M., Urrea, G., Magellan, G., Guasch, H., 2016. Short-term arsenic exposure reduces diatom cell size in biofilm communities. Environ. Sci. Pollut. R. 23, 4257-4270.

Biggs, B.J.F., Kilroy, C., 2000. Stream Periphyton Monitoring Manual. The New Zealand Ministry for the Environment, Christchurch.
Blanco, S., Cejudo-Figueiras, C., Tudesque, L., Bécares, E., Hoffmann, L., Ector, L., 2012. Are diatom diversity indices reliable monitoring metrics?. Hydrobiologia 695, 199-206.

Cantonati, M., Angeli, N., Virtanen, L., Wojtal, A.Z., Gabriell, J., Falasco, E., Lavoie, I., Morin, S., Marchetoo, A., Fortin, C., Smirnova, S., 2014. Achnanthidium minutissimum (Bacillariophyta) valve deformities as indicators of metal enrichment in diverse widely-distributed freshwater habitats. Sci. Total Environ. 75, 201-215.

Cattaneo, A., Couillard, Y., Wunsam, S., Courcelles, M., 2004. Diatom taxonomic and morphological changes as indicators of metal pollution and recovery in Lac Dufault (Québec, Canada). J. Paleolimnol. 32, 163-175.

Cho, E., Khim, J., Chung, S., Seo, D., Son, Y., 2014. Occurrence of micropollutants in four major rivers in Korea. Sci. Total Environ. 491-492, 138-147.

Coe, H.J., Kiffney, P.M., Pess, G.R., Kloehn, K.K., McHenry, M.L., 2009. Periphyton and invertebrate response to wood placement in large pacific coastal rivers. River Res. Appl. $25,1025-1035$.

Coste, M., Boutry, S., Tison-Rosebery, J., Delmas, F., 2009. Improvements of the biological diatom index (BDI): description and efficiency of the new version (BDI-2006). Ecol. Indic. 9, 621-650.

Cox, E.J., 1998. A rationale and some suggestions for developing rapid biomonitoring techniques using identification of live diatoms. Proceedings of the 15th International Diatom Symposium 43-50.

d'Ippolito, G., Sardo, A., Paris, D., Vella, F.M., Adelfi, M.G., Botte, P., Gallo, C., Fontana, A., 2015. Potential of lipid metabolism in marine diatoms for biofuel production. Biotechnol. Biofuels 8 (28), 1-10.

Debenest, T., Silvestrea, J., Coste, M., Delmas, F., Pinelli, E., 2008. Herbicide effects on freshwater benthic diatoms: induction of nucleus alterations and silica cell wall abnormalities. Aquat. Toxicol. 88, 88-94.

Duong, T.T., Morin, S., Coste, M., Herlory, O., Feurtet-Mazel, A., Boudou, A., 2010. Experimental toxicity and bioaccumulation of cadmium in freshwater periphytic diatoms in relation with biofilm maturity. Sci. Total Environ. 408, 552-562.

Einicker-Lamas, M., Mezian, G.A., Fernandes, T.B., Silva, F.L.S., Guerra, F., Miranda, K., Attias, M., Oliveira, M.M., 2002. Euglena gracilis as a model for the study of $\mathrm{Cu}^{+2}$ ? and $\mathrm{Zn}^{+2}$ ? toxicity and accumulation in eukaryotic cells. Environ. Pollut. 120, 779-786.

Falasco, E., Bona, F., Badino, G., Hoffmann, L., Ector, L., 2009. Diatom teratological forms and environmental alterations: a review. Hydrobiologia 623, 1-35.

Falasco, E., Bona, F., Ginepro, M., Hlúbiková, D., Hoffmann, L., Ector, L., 2009. Morphological abnormalities of diatom silica walls in relation to heavy metal contamination and artificial growth conditions. Water SA 35, 595-605.

Feld, C.K., Birk, S.D., Bradley, C., Hering, D., Kail, J., Marzin, A., Melcher, A., Nemitz, D., Pedersen, M.L., Pletterbauer, F., Pont, D., Verdonschot, P.F.M., Friberg, N., 2011. From natural to degraded rivers and back again: a test of restoration ecology theory and practice. Adv. Ecol. Res. 44, 119-209.

Fore, L.S., Grafe, C., 2002. Using diatoms to assess the biological condition of large rivers in Idaho (USA). Freshw. Biol. 47, 2015-2037.

Gautam, S., Pandey, L.K., Vinayak, V., Arya, A., 2017. Morphological and physiological alterations in the diatom Gomphonema pseudoaugurdue to heavy metal stress. Ecol. Indic. 72, 67-76.

Gillett, N., Pan, Y., Parker, C., 2009. Should only live diatoms be used in the bioassessment of small mountain streams?. Hydrobiologia 620, 135-147.

Gillett, N.D., Pan, Y., Manoylov, K.M., Stevenson, R.J., 2011. The role of live diatoms in bioassessment: a large-scale study of Western US streams. Hydrobiologia 665, 79-92.

Gold, C., Feurtet-Mazel, A., Coste, M., Boudou, A., 2002. Field transfer of periphytic diatom communities to assess short-term structural effects of metals (Cd, $\mathrm{Zn}$ ) in rivers. Water Res. 36, 3654-3664.

Guasch, H., Ricart, M., López-Doval, J., Bonnineau, C., Proia, L., Morin, S., Muñoz, I., Romaní, A.M., Sabater, S., 2016. Influence of grazing on triclosan toxicity to stream periphyton. Freshw. Biol. 61 (12), 2002-2012.

Hamilton, P.B., Lavoie, I., Alpay, S., Ponader, K., 2015. Using diatom assemblages and sulfur in sediments to uncover the effects of historical mining on LakeArnoux (Quebec, Canada): a retrospective of economic benefits vs. environmental debt. Front. Ecol. Evol. 3 (99), 1-16. 
Hammer, , Harper, D.A.T., Ryan, P.D., 2001. Past: paleontological statistics software package for education and data analysis. Palaeontol. Electron. 4 (1), art. 4: 9pp., $178 \mathrm{~kb}$.

Harding, W.R., Archibald, C.G.M., Taylor, J.C., 2005. The relevance of diatoms for water quality assessment in South Africa. Water SA 31, 41-46.

Hwang, S.-J., Lee, S.-W., Park, Y.-S., 2011. Ecological monitoring, assessment, and restoration of running waters in Korea. Ann. Limnol.-Int. J. Limnol. 47, S1-S2.

Ivorra, N., Hettelaar, J., Tubbing, G.M.J., Kraak, M.H.S., Sabater, S., Admiraal, W., 1999. Translocation of microbenthic algal assemblages used for in situ analysis of metal pollution in rivers. Arch. Environ. Con. Tox. 37, 19-28.

Kelly, M.G., Whitton, B.A., 1995. The trophic diatom index: a new index for monitoring eutrophication in rivers. J. Appl. Phycol. 7, 433-444.

Kelly, M., Juggins, S., Guthrie, R., Pritchard, S., Jamieson, J., Rippey, B., Hirst, H., Yallop, M., 2008. Assessment of ecological status in U.K. rivers using diatoms. Freshw. Biol. 53, 403-422.

Lavoie, I., Grenier, M., Campeau, S., Dillon, P.J., 2006. A diatom-based index for water quality assessment in eastern Canada: an application of Canonical Analysis. Can. J. Fish. Aquat. Sci. 63, 1793-1811.

Lavoie, I., Darchambeau, F., Cabana, G., Dillon, P., Campeau, S., 2008. Are diatoms good integrators of temporal variability in stream water quality?. Freshw. Biol. 53, 827-841.

Lavoie, I., Darchambeau, F., Cabana, G., Dillon, P., Campeau, S., 2008. Are diatoms good integrators of temporal variability in stream water quality?. Freshw. Biol. 53, 827-841.

Lavoie, I., Dillon, P.J., Campeau, S., 2009. The effect of excluding diatom taxa and reducing taxonomic resolution on multivariate analysis and stream bioassessment. Ecol. Indic. 9, 213-225.

Lavoie, I., Lavoie, M., Fortin, C., 2012. A mine of information: benthic algal communities as biomonitors of metal contamination from abandoned tailings. Sci. Total Environ. 425, 231-241.

Lavoie, I., Campeau, S., Zugic-Drakulic, N., Winter, J.G., Fortin, C., 2014. Using diatoms to monitor stream biological integrity in Eastern Canada: an overview of 10 years of index development and ongoing challenges. Sci. Total Environ. 475, 187-200.

Lavoie, I., Hamilton, P.B., Morin, S., Kim Tiam, S., Kahlert, K., Gonçalves, S., Falasco, E., Fortin, C., Gontero, B., Heudre, D., Kojadinovic-Sirinelli, M., Manoylov, D., Pandey, L.K., Taylor, J., 2017. Diatom teratologies as biomarkers of contamination: are alldeformities ecologically meaningful?. Ecol. Indic.)in press.

Leguay, S., Lavoie, I., Levy, J.L., Fortin, C., 2016. Using biofilms for monitoring metal contamination in lotic ecosystems: the protective effects of hardness and $\mathrm{pH}$ on metal bioaccumulation. Environ. Toxicol. Chem. 35 (6), 1489-1501.

Leira, M., Fillipi, M.L., Cantonati, M., 2015. Diatom community response to extreme water level fluctuations in two Alpine lakes: a core case study. J. Paleolimnol. 53, 289-307.

Liang, Y., Osada, K., Sunaga, Y., Yoshino, T., Bowler, C., Tanaka, T., 2015. Dynamic oil body generation in the marine oleaginous diatom Fistulifera solaris in response to nutrient limitation as revealed by morphological and lipidomic analysis. Algal Res. 12, 359-367.

Liu, Z.Y., Wang, G.C., Zhou, B.C., 2008. Effect of iron on growth and lipid accumulation in Chlorella vulgaris. Bioresour. Technol. 99, 4717-4772.

Luís, A.T., Teixeira, P., Almeida, S.F.P., Ector, L., Matos, J.X., Ferreira da Silva, E.A., 2011 Environmental impact of mining activities in the Lousal area (Portugal): chemical and diatom characterization of metal-contaminated stream sediments and surface water of Corona stream. Sci. Total Environ. 409, 4312-4325.

Morin, S., Duong, T.T., Dabrin, A., Coynel, A., Herlory, O., Baudrimont, M., Delmas, F., Durrieu, G., Schäfer, J., Winterton, P., Blanc, G., Coste, M., 2008. Long-term survey of heavy-metal pollution, biofilm contamination and diatom community structure in the Riou Mort watershed. South-West France. Environ. Pollut. 151, 532-542.

Morin, S., Pesce, S., Tili, A., Coste, M., Montuelle, B., 2010. Recovery potential of periphytic communities in a river impacted by a vineyard watershed. Ecol. Indic. 10, 419-426. http://dx.doi.org/10.1016/j.ecolind.2009.07.008.

Morin, S., Cordonier, A., Lavoie, I., Arini, A., Blanco, S., Duong, T.T., Tornés, E., Bonet, B., Corcoll, N., Faggiano, L., Laviale, M., Pérès, F., Becares, E., Coste, M., Feurtet-Mazel, A., Fortin, C., Guasch, H., Sabater, S., 2012. Consistency in diatom response to metal-contaminated environments. In: Guasch, H., Ginebreda, A., Geiszinger, A. (Eds.), Emerging and Priority Pollutants in Rivers. Springer- Verlag, Berlin, pp. 117-146.

Pandey, L.K., Bergey, E.A., 2016. Exploring the status of motility, lipid bodies, deformities and size reduction in periphytic diatom community from chronically metal $(\mathrm{Cu}, \mathrm{Zn})$ polluted waterbodies as a biomonitoring tool. Sci. Total Environ. 550, 372-381.

Pandey, L.K., Kumar, D., Yadav, A., Rai, J., Gaur, J.P., 2014. Morphological abnormalities in periphytic diatoms as a tool for biomonitoring of heavy metal pollution in a river. Ecol. Indic. 36, 272-279.

Pandey, L.K., Han, T., Gaur, J.P., 2015. Response of a phytoplanktonic assemblage to copper and zinc enrichment in microcosm. Ecotoxicology 24, 573-582.

Pandey, L.K., Ojha, K.K., Singh, P., Singh, C.S., Dwivedi, S., Bergey, E.A., 2016. Diatoms image database of India (DIDI): a research tool. Environ. Technol. Innov. 5, 148-160.
Pandey, L.K., Bergey, E.A., Jie, L., Park, J., Choi, S., Lee, H., Depuydt, S., Oh, Y.T., Lee, S.M., Han, T., 2017. The use of diatoms in ecotoxicology and bioassessment: insights advances and challenges. Water Res. 118, 39-58.

Patrick, R., Reimer, C.W., 1966. The Diatoms of the United States, vol. I. Monograph of the Academy of Natural Sciences of Philadelphia, Pennsylvania.

Patrick, R., Reimer, C.W., 1975. The Diatoms of the United States, vol. II. Monograph of the Academy of Natural Sciences of Philadelphia, Pennsylvania.

Pillai, S., Behra, R., Nestler, H., Suter, M.J.F., Sigg, L., Schirmer, K., 2014. Linking toxicity and adaptive responses across the transcriptome, proteome, and phenotype of Chlamydomonas reinhardtii exposed to silver. Proc. Natl. Acad. Sci. U. S. A. http:// dx.doi.org/10.1073/pnas.1319388111.

Ponader, K.C., Charles, D.F., Belton, T.J., 2007. Diatom-based TP and TN inference models and indices for monitoring nutrient enrichment of New Jersey streams. Ecol. Indic. 7, 79-93.

Ricciardi, F., Bonnineau, C., Faggiano, L., Geiszinger, A., Guasch, H., Lopez-Doval, J., Muñoz, I., Proia, L., Ricart, M., Romaní, A., Sabater, S., 2009. Is chemical contamination linked to the diversity of biological communities in rivers?. Trends Anal. Chem. 28, 592-602.

Round, F.E., Crawford, R.M., Mann, D.G., 1990. The Diatoms: Biology and Morphology of the Genera. Cambridge University Press, Cambridge, U.K.

Schallenber, M., Saulnier-Tablbot, , 2015. Trajectory of an anthropogenically inducted ecological regime shift in a New Zealand shallow coastal lake. Mar. Freshw. Res.

Silva, E.F., Almeida, S.F.P., Nunes, M.L., Luís, A.T., Borg, F., Hedlund, M., Sá, C.M., Patinha, C., Teixeira, P., 2009. Heavy metal pollution downstream the abandoned Coval da Mó mine (Portugal) and associated effects on epilithic diatom communities. Sci. Total Environ. 407 (21), 5620-5636.

Steinman, A.D., McIntire, C.D., 1990. Recovery of lotic periphyton communities after disturbance. Environ. Manage. 14, 589-604.

Stevenson, R.J., Pan, Y., 1999. Assessing environmental conditions in rivers and streams with diatoms. In: Stoermer, E.F., Smol, J.P. (Eds.), The Diatoms: Applications for the Environmental and Earth Sciences. Cambridge University Press, Cambridge, pp. $11-40$.

Stevenson, R.J., Pan, Y., Manoylov, K.M., Parker, C.A., Larsen, D.P., Herlihy, A.T., 2008 Development of diatom indicators of ecological conditions for streams of the western US. J. N. Am. Benthol. Soc. 27, 1000-1016.

Stevenson, R.J., Pan, Y., Vandam, H., 2010. Assessing environmental conditions in rivers and streams with diatoms. In: Smol, J.P., Stoermer, E.F. (Eds.), The Diatoms:applications for the Environmental and Earth Sciences, 2nd ed. Published by Cambridge University Press.

ter Braak C.J.F., Šmilauer, P., 2012. Canoco Reference Manual and User's Guide: Software for Ordination (version 5.0). Microcomputer Power www.canoco.com.

Tlili, A., Corcoll, N., Bonet, B., Morin, S., Montuelle, B., Bérard, A., Guasch, H., 2011. In situ spatio-temporal changes in pollution-induced community tolerance to zinc in autotrophic and heterotrophic biofilm communities. Ecotoxicology 20, 1823-1839.

Van Dam, H., Mertens, A., Sinkeldam, J., 1994. A coded checklist and ecological indicator values of freshwater diatoms from the Netherlands. Neth. J. Aquat. Ecol. 28, 117-133.

Verb, R.G., Vis, M.L., 2000. Comparison of benthic diatom assemblages from streams draining abandoned and reclaimed coal mines and non-impacted sites. J. N. Am. Benthol. Soc. 19, 274-288.

Villeneuve, A., Bouchez, A., Montuelle, B., 2011. In situ interactions between the effects of season, current velocity and pollution on a river biofilm. Freshw. Biol. 56, 2245-2259.

Wang, Z.T., Ullrich, N., Joo, S., Waffenschmidt, S., Goodenough, U., 2009. Algal lipid bodies: stress induction, purification and biochemical characterization in wild- type and starchless Chlamydomonas reinhardtii. Eukaryot. Cell 8, 1856-1868.

Winter, J.G., Duthie, H.C., 2000. Epilithic diatoms as indicators of stream total N and total P concentrations. J. N. Am. Benthol. Soc. 19, 32-49.

Wolska, L.W., Sagajdakow, A., Kuczyńska, A., Namieśnik, J., 2007. Application of ecotoxicological studies in integrated environmental monitoring: possibilities and problems. Trends Anal. Chem. 26, 332-344.

Wood, R.J., Mitrovic, S.M., Kefford, B.J., 2014. Determining the relative sensitivity of benthic diatoms to atrazine using rapid toxicity testing: a novel method. Sci. Total Environ. 485-486, 421-427.

Wood, R.J., Mitrovic, S.M., Lim, R.P., Kefford, B.J., 2016. How benthic diatoms within natural communities respond to eight common herbicides with different modes of action. Sci. Total Environ. 557-558, 636-643.

Yang, Z.K., Niu, Y.F., Ma, Y.H., Xue, J., Zhang, M.H., Yang, W.D., Liu, J.S., Lu, S.H., Guan, Y., Li, H.Y., 2013. Molecular and cellular mechanisms of neutral lipid accumulation in diatom following nitrogen deprivation. Biotechnol. Biofuels 6 (1), 1-14, (67).

Zalack, J.T., Smucker, N.J., Vis, M.L., 2010. Development of a diatom index of biotic integrity for acid mine drainage impacted streams. Ecol. Indic. 10, 287-295. 